\title{
COMMENTS
}

\section{RELUCTANT SOLDIERS: THE GRIMINAL LIABILITY OF CORPORATE OFFICERS FOR NEGLIGENT VIOLATIONS OF THE CLEAN WATER ACT}

\author{
Truxtun Hare $\dagger$
}

\begin{abstract}
If I were having a philosophical talk with a man I was going to have hanged (or electrocuted) I should say, I don't doubt that your act was inevitable for you but to make it more avoidable by others we propose to sacrifice you to the common good. You may regard yourself as a soldier dying for your country if you like.
\end{abstract}

Oliver Wendell Holmes ${ }^{1}$

\section{INTRODUCTION}

This century has witnessed the increasing use of federal statutes to impose criminal liability on corporate officers as a means of regulating corporate conduct that could result in harm to public health, safety and welfare. ${ }^{2}$ Some of these statutes require no scienter or mens rea element, thereby subjecting corporate officials to strict liability for actions or omissions in which they had a legally defined "responsible share"3 yet no direct participation or knowledge."

† B.A. 1961, Yale University; M.A. 1972, University of Chicago; J.D. Candidate 1990, University of Pennsylvania.

11 Holmes-Laski LetTers 806 (M. Howe ed. 1953).

2 See, e.g., Toxic Substances Control Act $\S \S 15-16,15$ U.S.C. $\S \S 2614-15$ (1988) (imposing civil and criminal liability on any person failing to comply with federal regulations regarding interstate commerce of toxic chemical substances); Wholesome Meat Inspection Act $\S 406,21$ U.S.C. $\S 676$ (1982) (imposing criminal liability on "any person, firm, or corporation" for violation of the Act, which regulates the production and distribution of meats)); Food, Drug, and Cosmetic Act $\$ \S 31-33,21$ U.S.C. $\$ \S 331-33$ (1982) (imposing criminal sanctions for violation of the Act, which regulates the interstate commerce of foods, drugs and cosmetics); Oil Pollution Act $\S 6,33$ U.S.C. $\S 1005$ (1982) (imposing criminal and civil penalties for wilfully discharging oil or oily mixture from a ship). For a past estimate of the pace of the federal government's increasing reliance on the "deterrent effect of criminal punishment to shape corporate action," see Note, Corporate Crime: Regulating Corporate Behavior Through Criminal Sanctions, 92 HARv. L. REv. 1227, 1229 \& n.5 (1979).

3 See infra notes 247-59 and accompanying text. The issue of who is or is not a 
Under this "responsible share doctrine," a trier of fact may find a corporate officer culpable if it determines that the officer, by reason of his status and position of responsibility in the corporation, had a responsible share in the furtherance of the transaction which the statute outlaws, regardless of his lack of awareness of the occurrence. ${ }^{5}$ Such an apparent abandonment of any mens rea standard raises disturbing questions when these officers are incarcerated without reference to whether or not they possessed culpable states of minds. ${ }^{6}$

"responsible" officer is central to this Comment in that the concept defines substantially the scope of the officer's liability. The Supreme Court has determined that the question of who falls within the scope of "responsible share" is a question to be decided by the trier of fact. See United States v. Park, 421 U.S. 658, 673-74 (1975); United States v. Dotterweich, 320 U.S. 277, 285 (1943). For a discussion of these cases, see infra text accompanying notes 243-59.

4 See, e.g., Park, 421 U.S. ar 673-74 (upholding a district court's criminal conviction of the president of a national food market chain under the Food, Drug and Cosmetic Act for food contaminated by rodent excreta, notwithstanding the fact that there was no proof of his knowledge of the contamination, because of the president's responsibility and authority either to prevent or to correct the violation). For two contrasting views of the scope of strict liability for responsible corporate officials under the Federal Food, Drug and Cosmetic Act, compare Abrams, Criminal Liability of Corporate Officers for Strict Liability Offenses-A Comment on Dotterweich and Park, 28 UCLA L. REv. 463, 470-76 (1981) (arguing that the Court's standard of liability is not really "strict," but rather contains an implicit culpable mental state contingent either on a departure from a standard of care or upon a presence of a certain measure of actual control over the situation) with Brickey, Criminal Liability of Corporate Officers for Strict Liability Offenses-Another View, 35 VAND. L. REv. 1337, 1343-46 (1982) (supporting a pure strict liability interpretation of Park's "responsible share" standard, requiring no culpable state of mind for corporate officers but rather focusing on the incorporation of the requirement of an act or omission in concert with the element of causation).

5 See Dotterweich, 320 U.S. at 284-85. For a discussion as to whether the mere "status" of the corporate officer, regardless of his knowledge, is sufficient for culpability to attach, see infra notes 134-37, 260-61 and accompanying text. There is clearly disharmony between Dotterweich and Park on this issue. The coinage of the phrase "responsible share," however, belongs entirely to Dotterweich. Id. at 284.

6 See, e.g., J. Hall, General Principles of Criminal Law 348 (2d ed. 1960) (noting that because strict liability violates the principles of any rational system of criminal law, "[w] hat then remains but the myth that through devious, unknown ways some good results from strict liability in 'penal' law?"); Packer, Mens Rea and the Supreme Court, 1962 SuP. CT. REv. 107, 150-51 (1962) ("No one should be sentenced to imprisonment or its equivalent without being afforded the opportunity to litigate the issue of mens rea or, to use the term adopted by the framers of the Model Penal Code, culpability."); Sayre, Public Welfare Offenses, 33 Colum. L. Rev. 55, 56 (1933) ("To inflict substantial punishment upon one who is morally entirely innocent, who caused injury through reasonable mistake or pure accident, would so outrage the feelings of the community as to nullify its own enforcement."). But see Brickey, supra note 4, at 1378-81 (supporting the Court's strict liability standard in the absence of a culpable state of mind in the context of the public welfare offense model); 
In contrast to these strict liability acts, other statutes provide for criminal sanctions only when there has been a knowing violation, thereby substantially increasing the prosecution's burden of proof. ${ }^{7}$ Resting between these two extremes is the Federal Water Pollution Control Act Amendments of $1972^{8}$ ("Clean Water Act"). ${ }^{9}$ It criminally sanctions, by a maximum of one year's imprisonment, "any person" 10 who negligently discharges a pollutant from a point source into navigable waters:

Any person who-(c)(1)(A) negligently violates section 1311, 1312, $1316,1317,1318,1328$, or 1345 of this title. .

...

shall be punishable by a fine of no less than $\$ 2,500$ nor more than $\$ 25,000$ per day of violation, or by imprisonment for not more than one year, or by both

(c)(6) For the purpose of this subsection, the term "person" means, in addition to the definition contained in section 1362(5) of this title, any responsible corporate officer. ${ }^{11}$

This Comment examines three pivotal public policy issues concerning the use of a negligence standard to criminally sanction corporate officers (as opposed to sanctioning the corporate entity) in

Wasserstrom, Strict Liability in the Criminal Law, 12 STAN. L. REv. 731, 744 (1960) (maintaining that, in reality, strict liability offenses are predetermined by the legislature to be per se unreasonable).

7 See, e.g., Lambert v. California, 355 U.S. 225 (1957) (holding that a municipal ordinance could not be enforced against someone who was reasonably unaware of its provisions); Resource Conservation and Recovery Act, 42 U.S.C. $\$ 6928$ (1982) (making it a crime for any person knowingly to transport hazardous waste to a facility without a permit); Packer, supra note 6, at 109 (asserting that the probable rationale behind Congress creating, and the courts accepting, strict liability criminal statutes may lie in the theory that "the conventional mens rea notion, that the actor must be consciously aware of the factors making his conduct criminal, places so heavy a burden on law enforcement that it is bound to be resisted").

8 Pub. L. No. 92-500, § 2, 86 Stat. 816 (1982) (codified as amended at 33 U.S.C. $\S \S 1251-1376$ (1982 \& Supp. 1987)). In 1987, Congress overrode a presidential veto and enacted major changes to this legislation. See 133 Cong. REc. H525-26 (daily ed. Feb. 3, 1987); 133 Cong. Rec. S1708 (daily ed. Feb. 4, 1987). The Clean Water Act has its origins in the Federal Water Pollution Control Act of 1948, Ch. 758, 62 Stat. 1155 (1948). See infra notes 70-91 and accompanying text for an analysis of changes to the criminal enforcement section of the Federal Water Pollution Control Act Amendments of 1972, 33 U.S.C. $\S 1319$ (c) (1982 \& Supp. 1987), as they apply to negligent violations.

9 This Comment refers to the amended legislation generally as the Clean Water Act, but to the 1972 Amendments specifically as the 1972 Amendments.

10 The term "person" specifically includes any "responsible corporate officer."

33 U.S.C. $\S 1319$ (c)(6) (1982 \& Supp. 1987).

1133 U.S.C. $\$ 1319$ (c)(1), (6) (1982 \& Supp. 1987). 
order to regulate corporate conduct. ${ }^{12}$ First, is it efficacious or just ${ }^{13}$ to imprison corporate officers for industrial accidents ${ }^{14}$ that may be ascribed to negligent decision-making and conduct? ${ }^{15}$ In balancing the potential sanctions imposed on the corporate entity itself against potential sanctions imposed on the officers who manage its affairs, is it more efficacious to punish the corporate entity, the individuals who manage that entity, or both ${ }^{16}$ Second, what degree of negligence is required for criminal culpability to attach? Is it the mere negligence standard of tort law, ${ }^{17}$ or does liability only attach when conduct falls somewhere further along the continuum towards the "gross negligence" of criminal common law? ${ }^{18}$ Third, in a negligence context, how broad is the sweep of the term "responsible" in the phrase "responsible corporate officer"? 19 To what extent does it impose vicarious liability? ${ }^{20}$ Specifically, how does the marrying of the terms "negligence" and "responsible" affect the defendant's culpability under the Clean Water Act's negligence standard? Does a "responsible corporate officer" have a higher duty of care and there-

12 See infra notes 218-27 and accompanying text for an analysis of the deterrent efficacy of criminally sanctioning the corporation in lieu of its officers.

13 See, e.g., J. HaLl, supra note 6 , at $135-41$ (arguing that criminal penalties for inadvertent harms, without requiring mens rea, is unjust); G. Williams, CRIminal Law: The General Part 98-100 (1953) (arguing that the criminal negligence standard lacks the necessary requirement of mens rea, and consequently that the use of the criminal negligence sanction for harms caused inadvertently is likely to be both inefficacious and unjust). But see Packer, supra note 6, at 109-10, 143-45. Packer argues that, on certain occasions, a criminal negligence standard can be a "half-way house" that tentatively extends the concept of mens rea with some deterrent efficacy. Packer further asserts that even though the standard ignores the actor's actual state of mind, the actor is punished for deviating unjustifiably from a generally accepted standard of conduct, thus the punishment has a "corrective function of promoting future awareness." Id. at 144.

14 The word, "accidents," is to be construed as connoting inadvertent events, not the "unavoidable" events to which Holmes' utilitarian theory of criminal sanctions speaks. See O. Holmes, The Common Law 48 (1881).

15 For a discussion of the view that sufficient vigilance, foresight, cost-benefit analyses and the expenditure of monies can reduce the incidence of the accidental pollution of the environment, see infra notes $188-90$ and accompanying text.

16 See infra notes 218-27 and accompanying text for discussion of the relative efficacy of sanctioning corporate officers versus sanctioning the corporate entity.

17 See infra notes 126-43 and accompanying text for an analysis of the mere negligence standard in relationship to the Clean Water Act.

18 See infra notes 173-99 and accompanying text for an analysis of common law negligence standards and the Model Penal Code's proposed criminal negligence standard which requires a "gross deviation."

19 See infra notes 246-64 for an analysis of cases developing the "responsible share" doctrine.

20 See infra note 59 and accompanying text for an analysis of the vicarious liability issue in the context of a negligence standard for corporate officers. 
fore a lower threshold for negligent culpability than would an ordinary "person" under the statute? ${ }^{21}$

The undefined reach of the Clean Water Act can be well illustrated by applying its framework to the recent oil spill by Exxon off the coast of Alaska. ${ }^{22}$ In this spill, a pollutant was negligently discharged from a "point source" into the "navigable waters," as those words are defined by the Act. ${ }^{23}$ But who may be deemed a "responsible corporate officer" such as would make him criminally liable under the Act? Those who continued to employ the captain while knowing of his history with alcohol? Or is such "knowledge" even a factor in determining "responsibility"? In a very large corporation such as Exxon, may the Chief Executive Officer himself be held criminally responsible despite his lack of any direct knowledge or direct supervisory responsibility? ${ }^{24}$ This Comment seeks to address these questions.

Fulfilling the Clean Water Act's goal of "restor[ing] and maintain[ing the] chemical, physical and biological integrity of our Nation's waters"25 clearly would achieve a vital "common good." From all sectors, concern has been rising that the increasing pollution of water resources endangers the public health, safety and welfare. ${ }^{26}$ Moreover, the leaders of the nation's industries, by their decisions regarding cost-benefit assessment, policy formation, and

21 See infra notes 119-25 and accompanying text for a discussion of the possible implications of combining the terms "negligence" and "responsible."

22 On March 24, 1989, the oil tanker Exxon Valdez ran aground at Prince William Sound, Alaska, creating the worst oil spill in United States history. See Largest U.S. Tanker Spill Spews 270,000 Barrels of Oil Off Alaska, N.Y. Times, Mar. 25, 1989, at 1 , col. 1. It has been alleged that the ship's third mate, who lacked the requisite Coast Guard authorization to operate a tanker, was in command of the Valdez at the time of the accident and that the ship's captain, Joseph Hazelwood, was intoxicated.

Apparently Exxon knew that Hazelwood had a problem with alcohol, but nevertheless allowed him to remain as the ship's captain. After the accident, Exxon's Chairman admitted that this decision was a "gross error." Oil Tanker Captain Fined After Failing Alcohol Test, Wash. Post, Mar. 31, 1989, at 1, col. I (quoting Lawrence Rawl, Chairman of Exxon).

2333 U.S.C. § 1251 (1982 \& Supp. 1987).

24 See Labaton, Does an Assault on Nature Make Exxon a Criminal?, N.Y. Times, Apr. $23,1989, \S 4$ (The Week in Review), at 1, col 3.

2533 U.S.C. $\S 1251$ (a) (1982).

26 Industrial pollution was perceived as one of the most serious crimes facing the nation. In 1984, when 60,000 people were asked to rank the severity of certain crimes for a published poll, environmental crime was allocated to seventh place, ahead of heroin smuggling and armed robbery. See Department of Justice, Bureau of Justice Statistics Bulletin (Jan. 1984). 
personnel supervision, have a major impact on the success or failure of achieving water-quality goals. ${ }^{27}$

The fundamental question raised by this Comment is whether the introduction to the Clean Water Act of a criminal negligence standard, coupled with the "responsible corporate officer" doctrine, achieves meaningful deterrence without vitiating the due process principles of the Constitution. Specifically, has there been a careful balancing of public interesis against due process personal liberty interests? ${ }^{28}$

Part I first reviews the historical use of strict liability criminal sanctions to regulate water pollution. ${ }^{29}$ It then examines the sanctioning framework developed around the negligence standard of the Clean Water Act and analyzes court decisions interpreting and refining the Act's criminal provisions. ${ }^{30}$

Part II examines the evolution of the negligence standard and its application to criminal law. It shows that the use of a tort ordinary negligence standard in criminal law amounts to a disguised extension of the strict liability concept, exhibiting the same inherent weaknesses as strict liability criminality. ${ }^{31}$

Part III analyzes the evolution of strict liability ${ }^{32}$ and the "responsible share" doctrine, suggesting that Supreme Court decisions confuse the two distinct issues of strict liability and vicarious liability and ignore the existence of due process issues. ${ }^{33}$ The Comment concludes by arguing that the introduction of a criminal negligence standard has not cured the due process weaknesses of the

27 The perception of many of those who work in environmental enforcement is that the failure to reach environmental goals often results from conscious costbenefit decisions by business owners and managers. For example, Judson Starr, former Environmental Crimes Unit Director for the Department of Justice Land and Natural Resources Division, asserts that the acts of corporate defendants (and of corporate officer defendants in particular) convicted for polluting the environment:

are generally willful, deliberate, rational, premeditated and committed with some forethought over a long period of time. . . [N]o perceptible defense is generally offered-except that compliance was too expensive. As a consequence, it usually can be said that the government was willfully cheated and the public betrayed . . . in terms of harm to the environment ... often by educated and privileged people who abuse their positions in society.

Starr, Countering Environmental Crimes, 13 B.C. Envtl. AFF. L. Rev. 379, 382 (1986).

28 See infra notes 95-101 and accompanying text.

29 See infra notes 36-69 and accompanying text.

30 See infra notes 84-92, 105-56 and accompanying text.

31 See infra notes $160-220$ and accompanying text.

32 See infra notes $234-45$ and accompanying text.

33 See infra notes 246-64 and accompanying text. 
earlier strict liability sanctions in cases where those sanctions can result in incarceration. ${ }^{34}$ It further suggests that the Clean Water Act's wedding of the "responsible share" doctrine to a negligence standard creates a circularity of analysis that tends to confuse any precise attribution of culpability. ${ }^{35}$

\section{The Evolution of Criminal Sanctions in Federal Water Pollution Regulations}

\section{A. The Refuse Act of 1899}

Case law since the turn of the century reveals substantial disagreement over the degree of culpability requisite for a criminal violation of environmental law. With respect to water pollution, the issue was raised first by the Rivers and Harbors Act of $1899^{36}$ ("Refuse Act"). This Act, as drafted, appeared to be a formidable tool for the deterrence of pollution, using criminal sanctions to proscribe any introduction of "refuse" into the navigable waters. ${ }^{37}$ Quite simply, the Refuse Act provided the legislatively innovative approach of imposing strict criminal liability on anyone who placed "refuse" into the nation's navigable waters. ${ }^{38}$ In 1906, Judge Aldrich, in In re Scow No. $36,{ }^{39}$ relied in part on innovations in British common law ${ }^{40}$ for authority to affirm this "somewhat recent rule created to meet the

34 See infra notes $278-87$ and accompanying text.

35 See infra notes $282-84$ and accompanying text.

36 The Rivers and Harbors Act provides: "It shall not be lawful to throw, discharge, or deposit, or cause, suffer, or procure to be thrown, discharged, or deposited either from or out of any ship ... or from the shore ... manufacturing establishment, or mill of any kind, any refuse matter of any kind, shape or description whatever other than that flowing ... in a liquid state into any navigable water . . .." Rivers and Harbors Act of 1899, ch. 425, § 13, 30 Stat. 1121, 1152 (1899) (emphasis added) (codified as amended at 33 U.S.C. $\$ \S 407,411$ (1982)).

3733 U.S.C. $\$ 411$ (1982)(providing that violation of the Refuse Act be punishable by fine and or "imprisonment (in the case of a natural person) for not less than thirty days nor more than one year").

38 See supra note 36.

39144 F. 932 (Ist Cir. 1906); see also United States v. Ballard Oil Co. of Hartford, Inc., 195 F.2d 369, 371 (2d Cir. 1952) (affirming sanctions under the strict liability standard of the Refuse Act against barge owner for the negligent discharge of oil).

40 See Scow, 144 F. at 933 ("The acts are properly construed as imposing the penalty when the act is done, no matter how innocently ... the substance of the [act being] that a man shall take care that the statutory direction is obeyed, and that if he fails to do so he does it at his peril." (quoting Regina v. Tolson, 23 Q.B. 168, 172-73 (1889)). 
demands of modern necessities." 41 Judge Aldrich readily asserted ${ }^{42}$ that strict criminal liability attaches to the offending act:

without regard to the question of wilfulness or intent, and without regard to the question of mistake or innocence. The rule is, of course, in derogation of the principles of the common law, and its drastic quality is justified upon [the] grounds of necessity, and as in the interest of the public good.

The expressed object of resorting to the exercise of plenary power through arbitrary and exceptional remedies ... is to better safeguard the public good in situations where the public good is easily subject to imposition and injury through heedless, inadvertent, or indifferent violations of laws enacted for the general welfare . . . ${ }^{43}$

Judge Aldrich conceptualized strict liability as a negligence offense, ${ }^{44}$ with the negligence element implicitly assumed; liability attached due to an "injury" caused by a "heedless" or "inadvertent" violation of a legislatively proscribed harm. ${ }^{45}$ The radical departure from common law negligence was that the state bore no burden of proof regarding a deviation from a standard of care. Actus reus swallowed mens rea, the two common law elements of proof being reduced to the one. ${ }^{46}$ Judge Aldrich's justification for what he termed this "derogation" of traditional principles was a need "to better safeguard the public good" where the public is subject to injury. ${ }^{47}$ Since the roots of both traditional criminal common law and contemporary statutory law presumably rise from a societal need to protect both "individual and public interests," 48 Judge Aldrich's

41 Id.

42 Perhaps Judge Aldrich might not have moved with such alacrity through the analytic steps of criminal strict liability if the issue was one of incarceration and not simply one of the collection of a fine. See id. (discussing pecuniary nature of sanctions).

43 Id. (emphasis added).

44 The same implicit use of a negligence standard in the strict liability context of the Refuse Act appears in United States v. Ballard Oil Co. of Hartford, Inc., 195 F.2d 369, 371 (2d Cir. 1952).

45 See Scow, $144 \mathrm{~F}$. at 933.

46 This reformulation of the traditional criminal common law elements of analysis of actus reus and mens rea is well expressed in contemporary terms by the analysis of George Fletcher: "The fault that need not be proved in cases of strict liability is not the fault of wrongdoing, but the fault of culpability. . . What makes the liability 'strict' is that the defendant's culpability need not be proven at trial." $G$. Fletcher, Rethinking Criminal Law $\$ 6.6 .3$, at 469 (1978).

47 Scow, 144 F. at 933.

48 See, e.g., Model Penal Codz $\$ 1.02$ (1962) ("The general purposes . . . are to forbid and prevent conduct that unjustifiably and inexcusably inflicts or threatens substantial harm to individual or public interests."). 
inability to articulate precisely the genesis of these "modern necessities"49 is unsurprising.

Prosecutorial enforcement of the Refuse Act did not parallel the Act's strict textual language,${ }^{50}$ however, as the legislative history of the Act was concerned primarily with navigational interference and not with water quality. ${ }^{51}$ Until 1970 , the primary prosecutions concerned the physical obstruction of navigation and related traumatic injuries. ${ }^{52}$ This interpretation dominated court rulings until. the 1960 s, when the Refuse Act was harnessed for a newly perceived set of needs. ${ }^{53}$

The impact of the Refuse Act was limited further by the use of fines in lieu of the available sanction of incarceration. ${ }^{54}$ Consequently, the issue of the deprivation of liberty for a strict liability offense never arose under the Refuse Act. ${ }^{55}$ The issue, however, was obliquely raised by its absence. In affirming the concept of strict liability under the Refuse Act in United States v. White Fuel Corporation, ${ }^{56}$ the First Circuit noted that because "a corporate defendant like White Fuel cannot be imprisoned, we need not consider to what extent absolute liability would carry over to cases where incarceration is a real possibility." 57 Accordingly, the court gingerly skirted the issue, merely footnoting a state case upholding a fine while

49 Scow, $144 \mathrm{~F}$. at 933.

50 For an in-depth analysis of the history of the Refuse Act, see Glenn, The Crime of "Pollution": The Role of Federal Water Pollution Criminal Sanctions, 11 AM. CRIM. L. REv. 835, 839-59 (1973).

51 See S. REP. No. 224, 50th Cong., lst Sess. 2 (1888) (expressing concern with regard to impediments to navigation caused by injurious pollution).

52 See, e.g., Kernan v. American Dredging Co., 355 U.S. 426, 427 (1958).

53 Note that the Refuse Act specifically excludes from its purview "refuse matter ... flowing from streets and sewers . . in a liquid state . . ." 33 U.S.C. $\$ 407$ (1982) (emphasis added). Obviously, water quality itself was not in the drafters' minds in the original legislation. The 1960 s, however, brought an interest in using the Refuse Act in a broader context. See, e.g., United States v. Standard Oil Co., 384 U.S. 224, 229 31 (1966) (construing the Refuse Act to include oil as a kind of "refuse" whose introduction into navigable waters violated the Refuse Act); United States v. Republic Steel Corp., 362 U.S. 482, 494 (1960) (discharge of industrial solids suspended in water through a sewer system violated the Refuse Act).

54 Cf. Glenn, supra note 50, at 837-45 (referring to a general lack of enforcement of the Refuse Act and mentioning instances of fines but none of incarceration).

55 This was largely true because most of the defendants convicted under the Refuse Act were corporations, not individuals. See, e.g., United States v. Ballard Oil Co. of Hartford, Inc., 195 F.2d 369, 371 (2d Cir. 1952) (fine imposed upon corporate defendant after navigation was impeded by corporation's oil spill in river).

56498 F.2d 619 (1st Cir. 1974).

57 Id. at 623-24. 
rejecting as unconstitutional a jail term based on vicarious liability. ${ }^{\mathbf{5 8}}$ The Supreme Court expressed the same gingerness nine years earlier in United States v. Standard Oil Co., ${ }^{59}$ when it sidestepped determining "what scienter requirement the [Refuse] Act imposes."60 Indeed, over a span of ninety years, the Supreme Court has deftly avoided deciding the issue of strict liability incarceration for a violation of the Refuse Act. ${ }^{61}$

Given that it only affirmed the fining of a corporation, rather than the incarceration of one of its officers, the White Fuel circuit court was as comfortable with the concept of strict liability as the judge in In re Scow No. 36 three quarters of a century earlier. ${ }^{62}$ The First Circuit relied heavily on Justice Jackson's strict liability analysis outlined in Morissette v. United States. ${ }^{63}$ Following Justice Jackson's lead, the First Circuit asserted that the Refuse Act fell within the domain of "public welfare offenses" for which neither scienter nor

58 See id. at $624 \mathrm{n} .9$ (footnoting Commonwealth v. Koczwara, $397 \mathrm{~Pa} .575,155$ A.2d 825 (1959) (reversing portion of sentence directing the incarceration of a tavern owner whose employee had sold liquor to a minor)). Koczwara asserts:

Liability for all true crimes, wherein an offense carries with it a jail sentence, must be based exclusively upon personal causation . . . . A man's liberty cannot rest on so frail a reed as whether his employee will commit a mistake in judgment .... Our own courts have stepped in time and again to protect a defendant from being held criminally responsible for acts about which he had no knowledge and over which he had little control.

Koczwara, $397 \mathrm{~Pa}$. at 585-86, $155 \mathrm{~A} .2 \mathrm{~d}$ at 830.

Note that the First Circuit took cognizance of a case on which the rejection of the sanction of incarceration was based on vicarious liability, not strict liability. See infra note 250 and accompanying text for a discussion of how the Supreme Court has muddied the distinction between these two concepts.

59384 U.S. 224 (1966).

$60 I d$. at 230 (refusing to consider what mens rea requirement the Act imposes, "as those questions are not before us in this restricted appeal").

61 It is possible, however, that the issue may yet arise. The United States Department of Justice's Indictments and Convictions Report for 1985 reports five convictions in that year under the Refuse Act. See McMurry \& Ramsey, Environmental Crime: The Use of Criminal Sanctions in Enforcing Environmental Laws, 19 LoY. L.A.L. Rev. 1133,1135 n.7 (1986).

62 See supra notes $39-49$ and accompanying text.

63342 U.S. 246 (1952). The Morissette Court explained that strict liability is appropriate for public welfare offenses since these offenses are defined statutorily and "are in the nature of neglect where the law requires care, or inaction where it imposes a duty." Id. at 255. Moreover, public welfare offenses endanger "the efficiency of controls deemed essential to the social order." Id. at 256 . Intent is not necessary because (1) the penalties are usually small, (2) conviction does not stigmatize one's reputation, and (3) "whatever the intent of the violator, the injury is the same, and the consequences are injurious or not according to fortuity." Id. 
negligence need be proven. ${ }^{64}$ In the tradition of prior Refuse Act court opinions, ${ }^{65}$ the First Circuit continued by noting that, in any case, "the government presented facts from which negligence could be inferred." 66 Citing the utilitarian theory of sanctions espoused by Holmes, ${ }^{67}$ the court asserted (with a rhetorical flourish that suggests some frustrations of its own) that there is a "benefit to society of having an easily defined, enforceable standard which inspires performance rather than excuses." 68

\section{B. The Clean Water Act}

As initially enacted, the Federal Water Pollution Control Act of $1948^{69}$ (now the Clean Water Act) provided no criminal sanctions for water polluters. The Act's prescribed pollution abatement procedures were so complex and convoluted that informal negotiations often proved more effective. ${ }^{70}$ In addition, federal civil actions were used only as a last resort. ${ }^{71}$ By 1971 , it appeared that prosecutors would not vigorously implement the sanctioning system of the Act. In fact, despite an amendment to the Refuse Act providing that "it shall be the duty of United States attorneys to vigorously prosecute all offenders,"72 the Attorney General of the United States was held to retain sole discretion in determining whether to prosecute a viola-

64 See United States v. White Fuel Corp., 498 F.2d 619, 622-23 (1974).

65 See supra note 4 and accompanying text for an analysis of other strict liability cases which use an implicit negligence standard.

66 White Fuel, 498 F.2d at 622.

67 See id. at 623 (citing O. Holmes, The Common LaW 49 (1881)).

68 Id. (emphasis added). Most, if not all, theorists of the criminal law see the concept of "excuse" as central to the development of the equitable attribution of criminal sanctions. See, e.g., G. FLETCHER, supra note 46, § 6.8.2, at 511 (suggesting that, even though there is an act of wrongdoing, the legal system "excuses" it when caused by circumstances such as blindness, infancy, or insanity). The First Circuit probably was referring to a broader concept of "excuse": the vain effort of White Fuel to use due care as an excuse against a strict liability statute. See White Fuel, 498 F.2d at 623.

69 Water Pollution Control Act, ch. 758, 62 Stat. 1155 (1948) (codified as amended at 33 U.S.C. $\S \S 1251-1387$ (1982 \& Supp. VI 1988)).

70 See Glenn, supra note 50, at $836 \mathrm{n} .7$; see also Comment, The Federal Water Pollution Control Act Amendments of 1972, 1973 WIS. L. Rev. 893, 893-95 (describing the Act's complex procedures).

71 See Glenn, supra note 50, at 836 n.7. For a thorough analysis of the enforcement history of the early decades of the Federal Water Pollution Control Act, see generally Barry, The Evolution of the Enforcement Provisions of the Federal Water Pollution Control Act: A Study of the Difficulty in Developing Effective Legislation, $68 \mathrm{MrcH}$. L. REv. 1103 (1970).

7233 U.S.C. $\S 413$ (1982). 
tor. $^{73}$ Even given the liberalized interpretation of the Act by the courts during the 1960s-an interpretation which addressed the issue of water quality as well as the issue of navigational obstructions-prosecutors continued to use the Act until 1970 only to pursue those violations which caused obstruction to navigation. ${ }^{74}$

By 1972 , in response to a groundswell of public opinion, ${ }^{75}$ Congress realized that the enforcement of federal law regarding water quality had not worked. This failure was due in large part to complex civil enforcement procedures and administrative red tape. ${ }^{76}$ In the legislative hearings preceding the Federal Water Pollution Control Act Amendments of 1972("1972 Amendments"), Senator Muskie noted that the nation had "ignored" the cancer of "water pollution," 77 asserting that "[o]ur planet is beset with a cancer which threatens our very existence and which will not respond to the kind of treatment that has been proposed in the past." ${ }^{.78}$ Another senator commented that " $[w]$ e have learned by disappointing experience ... that without strict enforcement and meaningful deterrents, water pollution control laws will have no real effect."79 The conclusion was that "the national effort to abate and control water pollution has been inadequate in every vital aspect" 80 and that " $[t]$ he record shows an almost total lack of enforcement. ... [, with] [o]nly one case ... reach[ing] the courts in more than two decades." 81

In this context the 1972. Amendments were passed with the perception that

sanctions under existing law have not been sufficient to encourage compliance with the provisions of the Federal Water Pollution Control Act.

[I]f the timetables established ... [for the restoration of the nation's water] are to be met, the threat of sanction must be real, and enforcement provisions must be swift and direct. Abatement orders, pen-

73 See Bass Anglers Sportsman's Soc'y of Am. v. Scholze Tannery, Inc., 329 F. Supp. 339, 345-46 (E.D. Tenn. 1971). For an analysis of this legislative-executive tension, see Glenn, supra note 50 , at $841 \mathrm{n} .27$.

74 See Glenn, supra note 50 , at 839 \& n.18.

75 See generally R. CARson, SiLEnt SpRING 173-98 (1962) (discussing how chemicals have leaked into all areas of nature and DDT is present in all foods).

76. See Glenn, supra note 50, at 836 n.7.

77118 Cong. Rec. 33,692 (1972) (statement of Sen. Muskie).

78 Id.

79 Id. at 33,716 (statement of Sen. Bayh).

80 S. Rep. No. 414, 92d Cong., 1st Sess. 7 (1971).

81 Id. at 5. 
alty provisions, and rapid access to the Federal District Court should accomplish the objective of compliance. ${ }^{82}$

The 1972 Amendments ${ }^{83}$ established a goal of complete elimination of the discharges of pollutants into navigable waters by $1985^{84}$ in order to "restore and maintain the chemical, physical, and biological integrity of the Nation's waters." 85 To achieve this ambitious goal, the 1972 Amendments imposed the criminal sanction of, inter alia, up to one year's imprisonment for any "person who willfully or negligently"86 discharges a pollutant from a point source ${ }^{87}$ into the navigable waters. ${ }^{88}$ While the same criminal sanctions ${ }^{89}$ were initially equally available for either negligent or willful violations, the Act, as currently amended, has changed the word "willfully" to "knowingly" and made more stringent sanctions available for knowing violations. ${ }^{90}$ Only the Act's civil penalties retain the Refuse Act's concept of strict liability. ${ }^{91}$ The Act further specifically

82 Id. at 64-65 (emphasis added).

83 Pub. L. No. 92-500, § 2, 86 Stat. 816, 816 (1972) (codified as amended at 33 U.S.C. $\S \S 1251-1376$ (1982 \& Supp. V 1987)).

8433 U.S.C. § 1251 (a)(1) (1982).

8533 U.S.C. $\S 1251$ (a) (1982).

8633 U.S.C. $\$ 1319$ (c)(1) (1982) provides that violators "shall be punished by a fine of not less than $\$ 2,500$ nor more than $\$ 25,000$ per day of violation, or by imprisonment for not more than one year, or by both."

87 A "point source" is "any discernible, confined and discrete conveyance . . . from which pollutants are or may be discharged." 33 U.S.C. $§ 1362(14)$ (1982 \& Supp. V 1987).

88 See 33 U.S.C. $\S 1311$ (1982). The terms of $\S 1311$ have the broadest inclusive sweep of any of the Clean Water Acts's seven proscribed paragraphs whose violation subjects the offender to criminal sanctions. See 33 U.S.C. $\S \S 1312,1316,1317,1318$, 1328, 1345 (1982 \& Supp. V 1987).

89 See supra note 86.

9033 U.S.C. $\$ 1319$ (c)(1)-(2) (Supp. V 1987). The term "wilfully" was changed to "knowingly" in the 1987 amendments and separated from "negligently" into its own sub-paragraph (§1319(c)(1) for negligent violations and $\S 1319$ (c)(2) for knowing violations). In contrast to negligent violations, the maximum penalty for knowing violations was doubled to $\$ 50,000$ for fines, and trebled to three years for incarceration. Negligent violations under $\$ \S 1311,1312,1316,1317,1318,1328$, or 1345 were criminalized. All of these paragraphs were criminalized as well for knowing violations. 33 U.S.C. $\S 1319$ (c)(1) (1982), as amended Feb. 4, 1987, Pub. L. No. 100$4, \S 312,101$ Stat. 7, 42 (1987) (codified as amended at 33 U.S.C. $§ 1319$ (c) (Supp. V 1987)).

9133 U.S.G. $\$ 1319$ (d) (1982 \& Supp. V 1987). It is interesting to note that, as currently amended, the maximum amount of the per-day fine for "civil violation" $(\$ 25,000)$ is the same as that for a fine assessed as a criminal negligent violation. See 33 U.S.C. $\S 1319$ (c)-(d) (Supp. V 1987). Since it is far easier to secure a conviction under the civil law's "preponderance of the evidence" burden of proof and its facilitated discovery procedures, the government's seeking a negligent criminal conviction requiring proof "beyond a reasonable doubt" makes sense only if the 
stipulated that "person" shall include "any responsible corporate officer." 92 As is demonstrated later in this Comment, the concept of "responsibility" has broad implications in the application of a negligence standard to the corporate setting. ${ }^{93}$

\section{The Implementation of the Clean Water Act}

Environmental violations and resultant injuries are exceedingly difficult to detect, so that, as one environmental prosecutor stated, even in "the most egregious cases, the harm will often not appear for years, or decades." 94 As a consequence, both legislative drafting and judicial interpretation of such legislation tend to make the sanctions stringent and the prosecutorial access to those sanctions efficient and flexible, thereby offsetting the inevitably small risk of discovery of any one individual polluter: ${ }^{95}$ In seeking to design and interpret laws that will influence industry's managers regarding potential harms to the Nation's water resources, however, the focus of both Congress and the courts has been more on the need for effective and immediate deterrence than on any balancing of that interest against the individual's due process rights. ${ }^{96}$ Although prosecutors often perceive the criminal sanctioning of the corporate entity as ineffective (since the corporation can only be fined and not jailed), they perceive the incarceration of the corporate officer as a potent prosecutorial weapon confronting the corporate manager personally

government intended to secure a sentence of incarceration for maximum deterrence impact.

9233 U.S.C. § 1319(c)(6) (Supp. V 1987).

93 See infra notes 246-64 and accompanying text. A major point stressed in this Comment is that since the concept of criminal "responsibility" has a standard of care that is implicit to its definition, the marriage of the "responsibility" concept to a negligence standard creates liabilities that may stretch well beyond the intentions of the framers of the Clean Water Act.

94 Starr, supra note 27 , at 383 .

95 See id. Starr asserts that "[f]or every case of criminal pollution that is detected and prosecuted, dozens, even hundreds, continue undetected and unabated. The penalty must, therefore, be large enough to deter others who ill-advisedly run the risk that their illegal activity will go undetected and unpunished." Id.

96 See infra notes 265-72 and accompanying text for a discussion of possible due process limitations to the imposition of the criminal sanction of imprisonment in the absence of any proof of mens rea. The Supreme Court, despite the protestation by legal scholars over the Court's passivity in the face of clear substantive due process issues, see Packer, Making the Punishment Fit the Crime, 77 HaRv. L. Rev. 1071, 1076-77 (1964), has tended to find any constitutional requirement of mens rea to be illusory. See infra text accompanying notes $\mathbf{2 3 4 - 4 2 .}$ 
and palpably. ${ }^{97} \mathrm{~A}$ corporation, prosecutors have learned, too often regards a fine as simply a "mere cost of doing business."98

A review of legal environmental literature reveals near unanimity in approving criminal sanctions aimed directly at corporate officials which could result in their incarceration. As one commentator rather cynically summarized:

Many companies amass vast fortunes and are willing to pay nominal fines in lieu of abating pollution. Nevertheless, jail a corporate officer who allows, or is in a position to know that his firm is allowing pollutants to reach our waters, and I am sure that he will quickly come to realize how important clean water really is and how its company can best eliminate his problems. ${ }^{99}$

Commentators have noted that "because of [the executive's] failure to supervise the activities of those under his control .... [and because] of the decentralization of the corporate body, many executives may [unwittingly] become criminals." 100 These commentators conclude ${ }^{101}$ that " $[t]$ he law should impose an affirmative duty upon the corporate official to discover and control."102

\section{Defining the Reach of the Clean Water Act}

By the mid to late 1970 s, the breadth ${ }^{103}$ of criminal liability created by the Clean Water Act began to be felt, in part due to the "charitable construction" of the act by the courts. ${ }^{104}$

In United States $v$. Hamel, ${ }^{105}$ the first case concluded successfully against an individual under the criminal provisions of the Clean

97 See Starr, supra note 27, at 383.

98 Id. at 382.

99 Lavin, Enforcement of Environmental Law on the Local Level, in ENVIRONMENTAL LAw 97 (C. Hasset ed. 1971).

100 Comment, The Criminal Responsibility of Corporate Officials for Pollution of the Environmenl, 37 ALB. L. REv. 61,71 (1972).

101 See id. at 71-72.

102 Id. at 71.

103 To give a far-fetched illustration of the breadth of this construction: Even a glass of hot water carelessly spilled onto a dry creek bed could technically put a person in violation of the criminal sanctions of the Clean Water Act. "Heat" is defined in $\S 1362$ as a pollutant. 33 U.S.C. $\S 1362(6)$ (1982). A glass is a "discrete conveyance" qualifying it as a "point source," 33 U.S.C. § 1362(14) (1982 \& Supp. V 1987), and even a dry creek bed is "navigable waters" under the interpretation of United States v. Phelps Dodge Corp., 391 F. Supp. 1181, 1187 (D. Ariz. 1975). While the discretion of federal prosecutors, judges, juries and appellate courts stands in the way of such a misuse of the Act, such interpretive breadth and scope nevertheless must give one pause.

104 See infra notes 106-12 and accompanying text.

105551 F.2d 107 (6th Cir. 1977). 
Water Act, the Sixth Circuit affirmed the conviction of a yard foreman for discharging hundreds of gallons of gasoline onto a frozen lake. ${ }^{106}$ The court construed the term "pollutant" to include the broad range of "any refuse matter" 107 stipulated by the Refuse Act, specifically noting the necessity that the "interpretation of water pollution legislation ... be given a generous rather than a niggardly construction."108 The court in United States v. Phelps Dodge Corporation $^{109}$ used the same generous statutory construction, construing the Clean Water Act as "public welfare" legislation. ${ }^{10}$ The court interpreted the Clean Water Act's prohibition of pollutant discharges into "navigable waters" as covering "any waterway, including normally dry arroyos, where any water ... might flow therein" to any body of water in which there is a "public interest."111

\section{The Appropriate Criminal Standard of Care}

Given no prior use of an ordinary negligence standard in a federal criminal statute, ${ }^{12}$ it is surprising that the standard was not specified or defined in the Clean Water Act, in the legislative history, ${ }^{113}$ or by federal appellate courts in the early years of the stat-

106 See id. at 108.

107 Id. at 110. The Clean Water Act's statutory definition of "pollutant" is quite broad even without judicial expansion: "The term 'pollutant' means dredged soil, solid waste, incinerator residue, sewage, garbage, sewage sludge, munitions, chemical wastes, biological materials, radioactive materials, heat, wrecked or discarded equipment, rock, sand, cellar dirt and industrial, municipal, and agricultural waste discharged into water." 33 U.S.C. $\$ 1362(6)$ (1982).

108 Hamel, 551 F.2d at 112 (citing United States v. Standard Oil Co., 384 U.S. $224,226(1966))$. The district court, however, also was "generous" in assigning the minimal criminal sanction allowed under the Clean Water Act, a fine of $\$ 2,500$, with neither probations nor incarceration.

109391 F. Supp. 1181 (1975).

110 Id. at 1186 . The District Court asserted: "We believe that ... the United States Congress was convinced that uncontrolled pollution of the nation's waterways is a threat to the health and welfare of the country ... ." Id. (quoting United States v. Ashland Oil \& Transp., 504 F.2d 1317, 1325 (6th Cir. 1974)).

111 Id. at 1187. Another district court followed this policy of using the "broadest possible constitutional interpretation" to determine that a spray irrigation system that oversaturated fields constituted a discharge from a "point source" into "navigable" waters. See United States v. Oxford Royal Mushroom Prods., 487 F. Supp. 852, 854-55 (E.D. Pa. 1980).

112 See infra note 180 and accompanying text.

113 The one anecdotal reference in the legislative history is made by Representative Harsha: "[I]n this legislation, we already can charge a man for simple negligence, we can charge him with a criminal violation under this bill for simple negligence." 118 ConG. REc. 33.695 (1972) (statement of Rep. Harsha). Such a brief and anecdotal comment by a legislator is not to be deemed strongly indicative of legislative intent. See, e.g., Brock v. Pierce County, 476 U.S. 253, 263 (1986) 
ute's tenure. Like water, the standard was allowed to seek its own level in the federal courts. In an early case brought under the Act, the court instructed the jury that an offense is committed negligently "if done wantonly and recklessly, manifesting an utter disregard for the law and the rights and safety of others."114 Not surprisingly, the application of that stringent standard resulted in an acquittal. ${ }^{15}$ Professor Rodgers, ${ }^{116}$ following the American Law Institute's proposal, advanced an alternative negligence standard for the Clean Water Act as "a gross deviation from the standard of care that a reasonable person would observe in the actor's situation."117

The standard, however, that dominates the courts' interpretation of the Clean Water Act is borrowed from tort's ordinary negligence: "The term 'negligence' means failure to use reasonable care. Reasonable care is the care which a reasonably careful person would use under similar circumstances." 118

A second anomaly appearing in the early implementation of the Clean Water Act was the prosecutors' practice of indicting defendants on a single charge of "willfully and negligently violating" the Act. ${ }^{119}$ Prosecutors viewed the addition of the negligence charge, working in concert with the "responsible corporate officer" doctrine, ${ }^{120}$ as a safety net for situations in which the carrying of the

(stating that statements by individual legislators should not be given controlling effect).

114 United States v. American Beef Packer, Crim. No. 74-0-30 (D. Nev. 1974), quoted in 2 W. Rodgers, ENvironmental LAw: Air and Water 603 n.101 (1986).

115 See id.

1162 W. RODGERs, supra note 114 , at 603 n.101.

117 Model Penal Code, supra note 48, at $\S 2.02(2)(d)$.

118 Court's Instructions, instruction \#21, United States v. Hoflin, No. CR8582T (W.D. Wash. Apr. 3, 1986), aff'd, 880 F.2d 1033 (9th Cir. 1989) (instructions on file with University of Pennsylvania Law Review).

119 See, e.g., United States v. Oxford Royal Mushroom Prods., Inc., 487 F.Supp 852, 855 (E.D. Pa. 1980) (holding that an indictment charging defendant with "willfully and negligently violat[ing]" the Clean Water Act is valid in that the mens rea required for negligent conduct and for willful conduct cannot be viewed as entirely distinct where defendant sprayed an overabundance of fertilizer on his fields so that some ran into a nearby stream); United States v. Hudson Farms, Inc., 12 Env't Rep. Cas. (BNA) 1445, 1446 (E.D. Pa. 1978) (noting that an indictment that charges "willfully and negligently violates" instead of "wilfully or negligently violates" is nevertheless one charge with the two adverbs merely specifying the "mode or method by which this proscribed conduct was accomplished"); see also Indictment, count 3, at 5, United States v. Hoflin, No. CR85-82T (W.D. Wash. Apr. 3, 1986) (charging defendant with "willfully and negligently violat[ing]" the Clean Water Act), aff'd, 880 F.2d 1033 (9th Cir. 1989) (Indictment on file with University of Pennsylvania Law Review).

120 See infra notes 243-61 and accompanying text. 
burden of proof on the element of scienter (willfully or knowingly) was in question. The former director of the Department of Justice Environmental Crimes Unit commented that, in United States v. A.C. Lawrence Leather Co., ${ }^{121}$ the president and vice president were charged with "failing to seek out, discover and stop" 122 the discharge of pollutants from the tannery into the adjacent river. "This doctrine," the former director asserted, "is available to prosecutors when the evidence indicates some willfulness by the executive who seeks to 'blind' himself from the occurrence of illegal acts performed within his bailiwick."123

The former director's words suggest that the negligence charge is applied to situations in which the government fully believes, but perhaps cannot prove beyond a reasonable doubt, that the defendants knowingly discharged pollutants. In such a situation, the negligence concept and the "responsible officer" concept are harnessed and married into a single and effective prosecutorial tool: the "responsible officer" becomes a "reasonably careful officer" who (1) should have known of a violation and therefore (2) failed in his duty to act on what he should have known. In this context the two standards, working in tandem, have the effect of exponentially increasing the scope of the negligence standard. ${ }^{124}$

\section{The Reach of the Clean Water Act's Negligence Standard}

With the broad foundations of prosecutorial discretion and statutory construction initially established, the Third Circuit focused major attention on the Clean Water Act's criminal negligence standard in United States v. Frezzo Brothers, Inc. ${ }^{125}$ Frezzo was the first case to consider in some depth the issue of an ordinary negligence ${ }^{126}$

121 Crim. No. 82-01-07-L (D.N.H. 1982).

122 Starr, supra note 27, at 391. Judson Starr is the former Environmental Crimes Unit Director for the Department of Justice Land and Natural Resources Division. See id. at 379 n.*. He served as a director from 1982-88. See 2 MartindaleHubbell Law Directory 1809B (122 ed. 1990).

123 Id. at 391 n.47.

124 See infra notes 241-59 and accompanying text for an analysis of the impact of marrying the "responsible officer doctrine" to the ordinary negligence standard. 125461 F. Supp 266 (E.D. Pa. 1978), aff'd, 602 F.2d 1123 (3d Cir. 1979), cert. denied, 444 U.S. 1074 (1980).

126 Restatement (Second) of Torts $\$ 282$ defines tort negligence as "conduct ... which falls below the standard established by law for the protection of others against unreasonable risk of harm." Re:statement (SEcond) of Torts $\$ 282$ (1965). Section 283 states that the standard is that of a "reasonable man under like circumstances." Id. at $\S 283$. Section 284 defines "conduct" to include (1) an act or (2) a failure to act where there is a duty to act. See $i d$. at $\$ 284$. 
criminal standard as applied to the federal "responsible corporate officer doctrine" where the issue of incarceration was involved. ${ }^{127}$ In Frezzo, the trial judge defined criminal negligence under the Clean Water Act "as the failure to do what a reasonably prudent person would do or to use ordinary care under the circumstances."128 The jury found the defendants (the president and secretary of a small corporation engaged in the growing of mushrooms) guilty of two counts of negligent violation of the Clean Water Act caused by the inadequate capacity of the corporation's holding-tank. The government's case was based on the theory that the holding-tank for manure composts "was too small to contain the compost wastes after a rainstorm." 129 As a consequence, when the manure overflowed into a stream after a rainfall, the defendants became criminally liable on the theory that they "had negligently discharged pollutants into the stream." 130

Some critics have derided Frezzo, one text dryly noting that the "government has amassed an impressive string of victories against small, family-owned mushroom companies."131 Frezzo offers an excellent paradigm, however, of an application of the negligence standard of the Clean Water Act to responsible corporate officers. ${ }^{132}$ While the district court commented that the defendant had "control and ownership of the premises"133 and that one brother knew that the holding-tank held all the water only "95\% of the time,"134

127 See Frezzo, 602 F.2d at 1130 n.11.

128 See infra note 157 and accompanying text for an analysis of other negligence standards that have been applied to Clean Water Act violations.

129 Frezzo, 602 F.2d at 1125.

$130 \mathrm{Id}$. Count five, a negligence count, was used to invoke the sanction of incarceration. See id. at 1130 n.10. The Frezzos were also found guilty of knowing violations on other counts, but the jail sentence was imposed only for the negligence violation. See id.

131 J. Bonine \& T. McGarity, The Law of Environmental Protection 941 (1984). The authors presumably were wondering why the government was not bringing such actions against larger industrial corporations whose conduct could have a far larger impact upon water quality. There could have been advantages for the government, however, in initially choosing defendants of limited financial means during the years when this fledgling standard of "ordinary negligence" was being interpreted initially by the courts. Of interest on this point is that the Frezzos dismissed their counsel following their unsuccessful appeal and came before the Third Circuit a second time on, among other issues, the question of constitutionally inadequate counsel. See United States v. Frezzo Bros., Inc., 642 F.2d 59, 63 n.15 (3d Cir. 1981).

132 This is true even though the Third Circuit relegated the "responsible corporate officer" doctrine to footnotes. See Frezzo, 602 F.2d at 1129 n.7, 1130 n.11.

133 Frezzo, 461 F. Supp. at 270.

134 Id. 
neither the district court nor the Third Circuit articulated what requisite facts were necessary for "responsibility" ${ }^{135}$ to attach. ${ }^{136}$

Furthermore, the Frezzo interpretation (in the context of a negligence charge) of the phrase "the discharge of any pollutant by any person shall be unlawful" changes the connotation of the word "discharge" from active to passive. One might argue that there was not, precisely speaking, a discharge made by the Frezzos. Rather, rain fell on a tank that at least one of these two corporate officers knew was not always large enough to contain the rain. ${ }^{137}$

To sustain an ordinary negligence conviction, all that is required is that a reasonable person or reasonable responsible corporate officer would have perceived the risk; no proof of knowledge is required. ${ }^{138}$ Once the relevant risks are isolated, a defendant is "negligent" if he fails to account for and correct these risks. As in Frezzo, this holds true regardless of whether the risk is unreasonably high or whether the defendant created the risk by careless conduct.

Thus, the "responsible corporate officer doctrine" extends the reach of the negligence standard by (1) determining which risks a responsible officer should know and then (2) holding that officer to an affirmative duty of care concerning those risks. ${ }^{139}$ Analytically, this theory of liability lies very close to a strict liability construct, but it is one that the judicial system applies retrospectively as opposed to true strict liability-a liability which a legislature imposes prospectively on a certain class of harms or conduct. ${ }^{140}$

135 The prosecution presented no evidence of scienter by the second brother, Guido Frezzo. He. . .was presumably sentenced to jail as a "responsible corporate officer" without any direct evidence that he had knowledge that the holding tank was only fully effective "95\% of the time." Thus, one way of interpreting Frezzo is that one of the defendants was sentenced to jail for his status as a corporate officer in a company which violated the Act, the requisite "responsibility" being inferred from that status. This is made possible because proof of subjective knowledge is not requisite for the violation of an ordinary negligence standard which measures culpability against a normative standard of what the actor should have known. See infra notes 158-81 and accompanying text.

136 Given the fact-pattern presented by Exxon's 1989 oil spill off Valdez, Alaska from a tanker that may have been negligently run aground, the officers of Exxon might all read Frezzo and pause. See supra note 22 and accompanying text.

137 See Frezzo, 461 F. Supp. at 270.

138 See supra note 118 and accompanying text for an analysis of the ordinary negligence standard of care.

139 See supra note 121 and accompanying text for the use of this same conceptualization to address a different prosecutorial problem in A.C. Lawrence Leather Co.

140 See Wasserstrom, Strict Liability in the Criminal Law, I2 STAN. L. REv. 731, 74445 (1960). 


\section{E. The Negligence Standard as Applied to Industrial "Accidents"}

The incarceration of the Frezzos also raises the additional issue of the use of incarceration to address industrial "design failures," for the Frezzos would not have been jailed if they had designed and installed a larger tank (or if less rain had fallen). The question thus posed for industry's managers is a vital one: when are they criminally liable for establishing policies and making cost-risk assessments both in the areas of plant equipment and in operational procedures? ${ }^{141}$ There have been at least two cases before the courts implicating this issue. The first and most notable case is United States v. Ashland Oil, Inc. ${ }^{142}$ On January 2, 1988, one of Ashland Oil's storage tanks collapsed, spilling more than 500,000 gallons of oil into the Monongahela River. ${ }^{143}$ On September 15, 1988, a federal grand jury indicted Ashland Oil for negligently violating the Clean Water Act. ${ }^{144}$ While only the corporation was indicted, those officers who could be deemed "responsible" for the design and installation of the tank certainly were subject to indictment during the ongoing "inquiry." 145 In fact, Ashland Oil had admitted that "routine tests weren't conducted on the tank ... and that following proper procedures might have prevented the vessel from rupturing."146

Precisely because strict liability statutes require an antecedent judgment of per se unreasonableness, they necessarily require a more general classification of the kind of activity which is to be regulated. They tend, and perhaps inherently so, to neglect many features which ought to be taken into account before such a judgment is forthcoming. Criminal negligence, on the other hand, demands an essentially a posteriori judgment as to the conduct in a particular case. As such, it surely provides more opportunity for the jury to consider just those facts which are most significant in determining whether the standard of care was observed.

Id.

141 See Starr, supra note 27, at 382-83 (arguing that businessmen's cost-benefit analyses can lead to the conclusion that it is cheaper to pay a fine if caught violating an environmental law than to correct the environmental hazard).

142 See Indictment at count 2, United States v. Ashland Oil Co., No. 88-146 (W.D. Pa. Aug. 3, 1988). The indictment alleges that "defendant ASHLAND OIL, INC. did negligently discharge and negligently cause to be discharged pollutants, including but not limited to oil, from a point source, including a storm drain, into the Monongahela River, a navigable water of the United States, without a permit." Id.

143 See id. at introduction.

144 See Wartzman, Ashland Faces Criminal Counts From Fuel Spill, Wall St. J., Sept. 16,1988 , at 48 , col. 4 .

145 See id.

146 Id. Ashland Oil was fined $\$ 2.25$ million and has paid approximately $\$ 18$ million in clean-up costs and civil claims. See \$2.25 Million Fine In '88 Spill, N.Y. Times, Mar. 10, 1989, at A16, col. 5 . 
In another case, United States v. Pennwalt Corp., a tank containing chemicals collapsed and allegedly spilled more than 75,000 gallons into an adjacent tidal waterway. ${ }^{147} \mathrm{~A}$ grand jury returned indictments against both the corporation and several corporate officers, charging them with "negligently ... discharg[ing] . . certain hazardous chemicals ... as the result of the collapse of a ... poorly maintained... steel storage tank."148 The government indicted the former vice president of the company's chemical division, the former president of the inorganic chemical division, and the former manager of manufacturing for the inorganic chemical division. Each of these individuals were corporate officers who, because of the large size of the company and the location of its corporate headquarters in Philadelphia, Pennsylvania, ${ }^{149}$ presumably only rarely (if at all) visited the Tacoma, Washington plant where the accident occurred.

The government asserted in a press release regarding Pennwalt that "[a]ccording to the Indictment, the defendants had a duty to establish and implement procedures to detect the presence of weakened structures used to store chemicals and to anticipate and perform such maintenance as necessary to prevent release of such chemicals." 150 The Assistant United States Attorney assigned to the case commented on the unique nature of the indictment, noting that "[i]t's one of the very first cases where a company is being charged with a crime without establishing criminal intent." 151 Eventually, the chief executive of Pennwalt entered a guilty plea on behalf of the corporation and agreed that: the corporation would pay a $\$ 1.1 \mathrm{mil}-$ lion fine. ${ }^{152}$

The language of the government's press release quoted above illustrates the potential commonality between the strict liability and negligence standards: "the defendants had a duty to ... perform such maintenance as necessary to prevent release of such chemicals." In other words, if chemicals are released, the duty has been per se violated. The key distinction, of course, is between the words "as necessary" and the words "as reasonably necessary," 153 as the latter

147 See United States Attorney for Western District of Washington, Department of Justice News Release 1-2 (May 20, 1988) [hereinafter News Release].

148 Id.

149 See 2 Moody's Industrial Manual 1988, at 4190-91.

150 News Release, supra note 147, at 2-3.

151 Egan, Putting a Face on Corporate Crime, N.Y. Times, July 14, 1989, at B8, col. 4 (emphasis added).

I52 See Pennwalt's Chief Officer Admits Company's Guilt, Wall St. J., Aug. 10, 1989, at C9, col. 1.

153 Indictment, count 1, at 5-6, United States v. Pennwalt, Inc., No. 88-55T 
allows the defense of due care. Even with the introduction of the concept of reasonableness, however, the definition of what constitutes due care may tend to change as one's perspective and timeframe change. Once a serious industrial accident occurs and criminal charges are brought, the jury must determine ex post what was "reasonable" conduct on the part of the corporate officer in fulfilling this affirmative duty of care. Yet, the corporate officer can only make that determination $a b$ initio in the context of his role as a financial planner and decision maker. The officer, of course, presumably is aware that his corporate superiors may assess his performance, in part, on its relation to the "bottom line."154 In contrast, however, the jury will make the legal evaluation of him performance with the luxury of hindsight and without the onus of concern for financial constraints.

\section{The Use of an Ordinary Negligence Standard in Criminal LAW}

The next two parts of this Comment address the issue of whether, as interpreted by the courts, any measurable degree of mens rea is required for conviction and incarceration under the criminal negligence standard of the Clean Water Act. Part II addresses the issue of the appropriateness of the use of an ordinary tort negligence standard as applied to the Act. Part III examines the impact of the "responsible corporate officer doctrine" as it interacts with the negligence standard in defining the scope and reach of liability.

\section{A. The Criminal Negligence Standard and Mens Rea}

Since the 1972 Amendments neither specify a negligence stan-

(W.D. Wash. May 18, 1988). The indictment, in contrast to the press release, uses the language "to anticipate and perform such maintenance as reasonably necessary to prevent releases of chemicals into the waters of the United States, and to take such other preventive steps as reasonably appropriate under the circumstances." Id. (emphasis added).

154 See Coffee, "No Soul to Damn: No Body to Kick": An Unscandalized Inquiry into the Problem of Corporate Punishment, 79 Mrch. L. REv. 386, 398-99 (1981). Coffee notes that the middle level manager is caught between Scylla and Charybdis: if he does not produce, he is always subject to being replaced. "He knows that if he cannot achieve a quick fix, another manager is waiting in the wings, eager to assume operational control over a division." Id. at 398 . Coffee suggests that the tensions inherent in the manager's job make him powerless in response to a "myopic notion of accountability that looks only to the bottom line of the income statement." Id. Of course, the in lerrorem possibilities of incarceration may serve the role of helping such a middle manager to don a more far-sighted pair of glasses. Perhaps this was precisely Congress's intent. Even so, the question remains: at what cost to the principles of due process and the constitutional protections accorded to individual liberties? 
dard in text nor identify a standard in the legislative history, ${ }^{155}$ the courts were left to determine the appropriate standard. ${ }^{156}$ While there were some differences in the Act's early years as to whether to use the common law's "gross negligence" standard or to borrow tort law's more rarely used (in terms of its criminal application) ordinary negligence standard, the ordinary negligence standard appears to be uniformly applied today. ${ }^{157}$

This leaves the Clean Water Act as the only instance in federal law in which ordinary negligence can result in criminal conviction and incarceration. ${ }^{158}$ Congress, in its expressed desire for "swift and direct" enforcement, ${ }^{159}$ presumably could have elected to incorporate the negligence-free strict liability standard of the Refuse Act, with its greatly eased burden of proof, ${ }^{160}$ into the Clean Water Act. Perhaps, however, Congress heard a subtle warning in the Supreme Court's reserving the issue of the constitutionality of incarceration for a strict liability offense in Standard Oil Co. and sought to head off a confrontation on this issue. ${ }^{161}$ Whatever its motive, Congress chose to add the element of at least a nominal mens rea negligence standard when it introduced criminal sanctions in the 1972 Amendments. In fact, the 1972 Amendments' legislative history states that the penalty of imprisonment would be provided only for "knowing" violations. ${ }^{162}$ While most theorists do not consider negligence to be a "knowing violation" (in that negligence is assessed as a deviation from a normative judgment and not as an actual subjective state of

155 See supra note 113 and accompanying text.

156 See supra notes $114-18$ and accompanying text for the initial disharmony among the negligence standards used by district courts.

157 In United States $v$. Hofln, the court's instructions read: "The term 'negligence' means failure to use reasonable care. Reasonable care is the care which a reasonably careful person would use under similar circumstances." Court's Instructions, instruction \#21, United States v. Hoflin, No. CR85-82T (W.D. Wash. Apr. 3, 1986), aff'd, 880 F.2d 1033 (9th Cir. 1989).

158 See infra note 180 for a discussion of the treatment of involuntary manslaughter under federal law.

159 See supra notes 77-93 and accompanying text for an analysis of the legislative history of the Clean Water Act.

160 See Abrams, supra note 4, at 473 ("One of the traditional functions of a strict liability approach is to relieve the prosecution of having to prove culpability in conditions of a large caseload or where culpability is likely to be present and yet may be difficult to prove.").

161 See supra note 59-61 and accompanying text.

162 "The Committee further recognizes that sanctions under existing law have not been sufficient to encourage compliance with the provisions of the Federal Water Pollution Control Act. Therefore, the Committee proposes to increase significantly the penalties for knowing violations ..." S. REP. No. 414, 92d Cong., Ist Sess. 5 (1971). 
mind $\left.{ }^{163}\right)$, the drafters apparently equated negligence with "knowing."164

One possible explanation for the absence of a definition or an explanation of intent regarding the negligence standard in the Clean Water Act is that using an undefined negligence standard in the Act may reflect Congress' reluctance to depart from the Refuse Act's strict liability standards. ${ }^{165}$ The negligence standard thus acts as a prosecutorial safety net to snare violators when subjective knowing could not be proven beyond a reasonable doubt. ${ }^{166}$ In this respect, the Act's negligence standard, when interpreted as ordinary negligence and coupled with the "responsible corporate officer" doctrine, serves as a crude replacement for the Refuse Act's strict liability standard. ${ }^{167}$

Under common law, however, normally "[m]ere negligence or carelessness is not enough to impose criminal liability .... The conduct of accused must have been such as to show an utter, ... wanton disregard for the safety or rights of others who might reasonably be expected to be injured thereby."168 In most instances, criminal liability only attached when there was a finding of gross negligence or carelessness and "some measure of wantonness or recklessness."169 LaFave and Scott postulate that the "something extra" required of the common law's criminal negligence standard was either (1) conduct that typically created a higher degree of risk than that required by tort negligence, or (2) conduct characterized by the defendant's conscious realization of the risk being created. ${ }^{170}$ The former criterion obviously requires a higher level of negligence than tort negli-

163 See G. Fletcher, supra note 46, § 6.2.1, at 396-401.

164 One says "apparently" simply because there was no recorded discussion or definition given to this newly federalized negligence standard. See supra note 113 and accompanying text.

165 See Olds, Unkovic, \& Lewin, Thoughts on the Role of Penalties In the Enforcement of the Clean Air and Clean Water Acts, 17 DuQ. L. REv. I, 16 n.62 (1978).

$160 \mathrm{Cf}$. Abrams, supra note 4 , at 473 (noting that strict liability relieves the already burdened prosecutor from proving culpability). The government's burden of proof in criminal cases ("beyond a reasonable doubt") is so great that there may be some legislative inclination simply to reduce what needs to be proven. Judge Learned Hand fervently expressed the frustrations attendant on this prosecutorial burden as follows: "Under our criminal procedure the accused has every advantage. ... He is immune from question or comment on his silence; he cannot be convicted when there is the least fair doubt in the minds of any one of the twelve." United States v. Garsson, 291 F. 646, 649 (S.D.N.Y. 1923).

167 See supra notes $36-42$ and accompanying text.

168 65A C.J.S. Negligence $\S 306$, at 1074 (2d ed. 1966).

169 Id. at 1074-75.

170 See W. LaFave \& A. Scott, Criminal Law 232 (2d ed. 1986). 
gence, in that it necessitates a greater showing of ignored risk to impose liability. The latter criterion is, of course, absent from the concept of ordinary tort negligence, ${ }^{171}$ which only asks what a reasonable person would have done under the circumstances, without inquiry into the subjective state of mind of the actor. This difference between tort and criminal law negligence is justified by the different goals of these areas. Excluding the role of punitive damages, the arguable goal of tort law is the restitution of the injured, whereas the criminal law seeks punishment of the actor. ${ }^{172}$

More than a century ago, however, Holmes implicitly suggested that tort and criminal law have a common core, in that "when men live in a society, a certain average of conduct, a sacrifice of individual peculiarities going beyond a certain point, is necessary to the general welfare."173 Perhaps, then, general deterrence, not personal subjective culpability, is the central purpose of laws that attach criminal liability to mere ordinary negligence. ${ }^{174}$ General deterrence is typically of paramount importance when the risk of harm runs high, as in statutes criminally penalizing negligent driving that results in death $^{175}$ or in trials finding parents criminally liable for the neglect of their children. ${ }^{176}$

171 See, e.g., RESTATEMENT (SeCOND) OF TORTs, supra note 126, at $\$ 282$ (defining tort negligence as "conduct which falls below the standard established by law for the protection of others against unreasonable risk of harm"); id. at $\S 283$ (defining the required standard of conduct as "that of a reasonable [person] under like circumstances"); id. at $\$ 284$ (defining conduct to include (1) an act or (2) a failure to act where there is a duty to act).

172 See Fletcher, Fairness and L'tility in Tort Theory, in Perspectives on TORT Law 239, 244-45 (R. Rabin ed. 1983). But see G. Calabresi, The Costs of Accidents 2 I, 26-29 (1970) (making accident-causing conduct expensive is a way of fostering general deterrence).

173 O. Holmes, supra note 14 , at 108.

174 See supra note 1 and accompanying quotation for Holmes' thoughts on this debatable subject.

175 See, e.g., State v. Pope, 6 Conn. Cir. Ct. 712, 313 A.2d 84 (1972); State v. Miles, 203 Kan. 707, 457 P.2d 166 (1969); Commonwealth v. Burke, 6 Mass. App. Ct. 697, 383 N.E.2d 76 (1978); People v. Hill, 16 Mich. App. 229, 167 N.W.2d 799 (1969). See generally Annotation, What Amounts to Negligence Within The Meaning of Statutes Penalizing Negligent Homicide by Operation of a Motor Vehicle, 20 A.L.R.3d 473 (1968) (citing opinions from the District of Columbia and ten states for the proposition that " $[\mathrm{m}]$ any cases have held or recognized that a showing of ordinary negligence is sufficient to convict an accused under a vehicular negligent homicide statute describing the punishable misconduct in terms of 'negligence' without any modification or qualification being attached to such a word").

176 For example, in one much discussed case, an American Indian couple were convicted of manslaughter when their child died from an untreated infected tooth even though the parent's "ordinary negligence" appeared to be a consequence of their lack of education and their fear that white doctors would take their child away 
State courts provide no uniform answer to the question of whether using a negligence standard as a criminal standard requires a high degree of negligence, knowledge of risk, neither, or both, ${ }^{177}$ and state legislatures feel free to provide criminal sanctions for a broad range of merely negligent conduct, including, for example, "willfully or negligently allow[ing] . . . livestock to run at large."178 Federal law, however, avoids the use of a criminal negligence standard except in the Clean Water Act and in a federal involuntary manslaughter charge in which the statute reads "without due caution and circumspection."179 In light of the way the courts have interpreted the Clean Water Act, the federal courts curiously interpret the involuntary manslaughter statute's language of "with due care and circumspection" as requiring a showing of "gross negligence."180 Furthermore, under this interpretation of gross negligence, the actor must have been aware of the risk. ${ }^{181}$ The fact that, in stark contrast, the federal courts' interpretation of the Clean Water Act has gravitated to both ordinary negligence and an objective standard of care perhaps shows the different treatment accorded statutes that come under the public welfare domain.

\section{B. The Model Penal Code}

The Model Penal Code ("Code") presents a compromise between the tensions inherent in the conflicting standards described in the above section. The Code defines criminal negligence to require a relatively objective standard of care, but it also requires a gross deviation from that standard. Specifically, the Code recommends that criminal liability should attach to negligence only when there is a gross deviation from the standard of care that a reasonable person in the actor's situation would use. ${ }^{182}$ This standard still holds

from them. They simply had no knowledge of their "negligence." See State v. Williams, 4 Wash. App. 908, 484 P.2d 1167 (1971).

177 See W. LaFave \& A. ScotT, Handbook on Criminal Law $\S 30$, at 208-18 (1972).

178 WASH. REV. CODE $\$ 16.24 .065$ (1988).

17918 U.S.C. $\$ 1112$ (a) (1982).

180 See United States v. Benally, 756 F.2d 773, 776 (10th Cir. 1985) (stating that federal law requires gross negligence with actual or constructive knowledge of risk to sustain a charge of involuntary manslaughter (citing United States v. Keith, 605 F.2d 462,463 (9th Cir. 1979)).

181 See id.

182 See Model Penal Code, supra note 48 , at $\S 2.02(2)(d)$ commentary. The Code defines criminal negligence as follows:

A person acts negligently with respect to a material element of an offense when he should be aware of a substantial and unjustifiable risk that the 
the actor to an objective standard of a reasonable person, but it seeks to put this reasonable person in the shoes of the actor. ${ }^{183}$ The effort of asking the trier of fact to adopt momentarily the perceptions of the actor thus satisfies a crucial step in the rational attribution of criminal sanctions to wrongful acts. ${ }^{184}$ " $[$ C]ould the actor have been fairly expected to avoid the act of wrongdoing? Did he or she have [a] fair opportunity to perceive the risk?" 185 Since under this conceptualization the actor is only liable if he should have known of the risk, one critic notes that the question posed by the Code formulation is "whether the actor can fairly be blamed for not knowing of the risk." 186 The Code further asks the trier of fact to evaluate the nature of the risk as one that a reasonable person would recognize as both "substantial" and "unjustifiable." ${ }^{187}$ Accordingly, the taking of such a risk "does not even raise a question of liability ... unless the social costs outweigh the benefits of the risk and therefore render it 'unjustified." 188 Culpability derives, then, "not from the choice to violate a legal imperative, but from the failure to meet reasonable standards of attentiveness." 189

While the Code's definition of criminal negligence uses what might be termed a "synthetic" mens rea ${ }^{190}$ because the actor in fact may not be aware of the risk, ${ }^{191}$ it does provide due process safe-

material element exists or will result from his conduct. The risk must be of such a nature and degree that the actor's failure to perceive it, considering the nature and purpose of his conduct and the circumstances known to him, involves a gross deviation from the standard of care that a reasonable person would observe in the actor's situation.

Id.

183 See id.

184 Fletcher argues that the careful analysis of the issue of culpability in the criminal law requires recognition that an act can be "wrong" without requiring punishment. If an insane man murders another he has committed a wrongful act, but society does not "attribute" culpability to him. In essence, he is "excused." See G. Fletcher, supra note $46, \S 6.8 .2$, at 511-12.

185 Id. $\$ 6.8 .1$, at 510 .

186 Id. $\$ 6.6 .6$, at 485 .

187 See Model Penal Code, supra note 48, at $\S 2.02(2)(d)$.

188 G. FletCher, supra note $46, \S 4.3$, at 261 .

189 Id. $\S 4.3$, at 262.

190 See Packer, supra note 6, at 143 (stating that negligence is the "absence of a state of mind. . . . an extension rather than an example of the idea of mens rea in the traditional sense" (footnote omitted)).

191 The drafters of the Model Penal Code were quite aware of the limitations of this newly defined concept of mens rea:

The fourth kind of culpability is negligence. It is distinguished from purposeful, knowing or reckless action in that it does not involve a state of awareness. A person acts negligently under this subsection when he 
guards for the accused. First, it defines the nature of the risk taken and a reasonable standard of care to be exercised towards such a risk. Second, it defines a failure of perception that forms the basis of culpability. As with strict liability, such a standard imposes sanctions based on an external standard that ignores the actual state of mind of the offender. ${ }^{192}$ This criminal negligence standard, however, attributes liability quite precisely to the absence of a particular state of mind. ${ }^{193}$ It provides to the trier of fact a method of analysis for determining when the actor is required by law both to perceive certain risks and to act on those perceptions. Thus, even without the Code's additional requirement of a "gross deviation" from the standard of care, ${ }^{194}$ the use of its carefully defined, step by step negligence standard as a jury instruction applicable to the Clean Water Act would afford the trier of fact the opportunity to examine whether or not the absence of a defined particular state of mind was a culpable absence in the actor's situation. This allows for a far more precise determination of criminal culpability than that reached under the current federal court interpretation of the Clean Water Act's negligence standard as mere ordinary negligence. ${ }^{195}$

\section{G. A Review of Critical Commentary on the Issue of Culpability}

The notions that the criminal sanction of incarceration should not attach to strict liability offenses and that deprivation of liberty should only attach when subjective culpability is present are wide-

inadvertently creates a substantial and unjustifiable risk of which he ought to be aware. $\mathrm{He}$ is liable if given the nature and degree of the risk, his failure to perceive it is, considering the nature and purpose of the actor's conduct and the circumstances known to him, a gross deviation from the care that would be exercised by a reasonable person in his situation. . . . And again it is quite impossible to avoid tautological articulation of the final question. The tribunal must evaluate the actor's failure of perception and determine whether, under all the circumstances, it was serious enough to be condemned.

Model Penal Code, supra note 48, $\$ 2.02$ commentary (emphasis added).

192 See Packer, supra note 6, at 138. Packer praises the Model Penal Code in that "[i]t can be shown that criminal conduct involves . . . an act or omission, the accompanying circumstances, and the result. The important basic insight of the Code's framers is that the requisite mental element for a criminal offense must, in the interest of clear analysis, be faced separately with respect to each material element of the offense." Id. (footnote omitted).

193 See id. at 144.

194 See Model Penal Code, supra note 48, at $\$ 2.02(2)$ (d).

195 See supra notes 114-17 and accompanying text for some examples of early disharmony in the choice of an appropriate negligence standard. 
spread and pervasive. ${ }^{196}$ Herbert Packer is only one of many scholars to condemn the criminalization of nonculpable conduct. $\mathrm{He}$, however, tentatively theorizes that the introduction of a negligence standard into strict liability statutes could function as a "halfway house," 197 serving as a way of balancing the legislative need for clear deterrence of conduct endangering public safety against at least the theoretic issue of culpability raised in the objective terms of a reasonable man's conduct. By raising at least the issue of an objective standard of culpability, Packer hypothesizes, the "tyranny of strict liability" can be avoided. ${ }^{198}$ There would be a theoretic "blameworthiness" in the actor's deviation from the generally accepted standard of conduct, and the actor's conviction could "serve the corrective function of promoting future awareness." 199 Packer seems tentatively willing in his analysis to "occasionally" sacrifice a subjectively non-blameworthy individual to promote the greater good of "future awareness."200 Compared to Holmes, however, Packer was not nearly as convinced of the utilitarian necessity of such a sacrifice. ${ }^{201}$ Holmes appeared certain that "justice to the individual is rightly outweighed by the larger interests [of preventing harm] on the other side of the scales." 202 Holmes believed that the proper

196 See, e.g., J. Feinberg, Doing and Deserving: Essays in the Theory of RESPONSIBILITY 1 1 1-12 (1970) ("[S]trict liability to imprisonment . . . "has been held by many to be incompatible with the basic requirements of our Anglo-American ... jurisprudence' .... [T] [There is something very odd and offensive in punishing people for admittedly faultless conduct. . . " (quoting Wasserstrom, supra note 6, at 70)); H.L.A. HaRt, Punishment and Fiesponsibility 152 (1968) (asserting that "strict liability is odious, and appears as a sacrifice of a valued principle [in that] . . those whom we punish should have had, when they acted, the normal capacities . . . for doing what the law requires and abstaining from what if forbids"); Packer, supra note 6 , at 109 ("[T]o punish conduct without reference to the actor's state of mind is both inefficacious and unjust .... It is unjust because the actor is subjected to the stigma of a criminal conviction without being morally blameworthy.").

197 See Packer, supra note 6, at 109-10 (citing G. Williams, supra note 13, at 271).

198 See id. at 110.

199 Id. at 144; see also Dubin, Mens Rea Reconsidered: A Plea for a Due Process Concept of Criminal Responsibility, I8 STAN. L. Rev. 322, 390 (1966) ("The diligence doctrine is one important way in which a balance can be struck between the demands of society for increased protection and the requirement that the criminal law not encroach unjustly upon the liberty of the individual.").

200 In fairness to Packer, he recommends the use of a negligence standard to impose criminal liability only on "occasion . . . [and] not as a matter of course." Packer, supra note 6, at 144-45.

201 See supra note 1 and accompanying quotation by Holmes.

202 O. Holmes, supra note 14 , at 48 . 
function of the criminal law was to "sacrifice[] the individual to the general good" when necessary. ${ }^{203}$

Packer, on the other hand, notes that to punish conduct without clear reference to an actor's state of mind "is both inefficacious and unjust" and will not deter others from behaving similarly in the future. ${ }^{204}$

The traditional justifications for imposing criminal sanctions have tended to fall under four rationales: rehabilitation, incapacitation, deterrence and retribution. ${ }^{205} \mathrm{~A}$ broad in terrorem application of the Clean Water Act's criminal sanctions may inject a degree of fear into most individual corporate decision making, thereby creating general wholesale deterrence of all conduct that might conceivably impact upon water pollution. ${ }^{206}$ Other traditional sanctioning rationales, however, may not apply in the corporate context of the officer who makes "good faith" economic decisions regarding plant, equipment or procedures that prove, after analyzing an industrial accident with the benefits of hindsight, to be ill-advised.

This Comment does not suggest that the federal courts, in interpreting the Clean Water Act to require an ordinary tort negligence standard, necessarily make rigid Holmesian utilitarian sacrifices of individual liberty interests. ${ }^{207}$ Rather, the courts seem to have followed a traditional strict liability notion of lowering the level of

203 Id. The legal theories of Holmes as scholar are not always consonant with his pronouncements as judge. In United States v. Behrman, 258 U.S. 280 (1922), one of a triad of cases that established the foundations of strict liability criminal law in the United States, the majority determined that a doctor's sale of drugs without proof of scienter constituted a criminal offense, holding that "[i]f the offense be a statutory one, and intent or knowledge is not made an element of it, the indictment need not charge such knowledge or intent." Id. at 288. The Court considered irrelevant the defendant's good-faith belief that his conduct in dispensing narcotics was in keeping with his professional medical standards. See id.

In vehement dissent, Justice Holmes noted that since the "defendant was a licensed physician and his part in the sale was the giving of prescriptions ...., it must be assumed that he gave them in the . . course of his practice and in good faith .... It seems to me impossible to construe the statute as tacitly making such acts, however foolish, crimes." Id. at 290 (Holmes, J., dissenting). Perhaps the implicit distinction here for Holmes was that he saw no general deterrence value or "general good" to be gained from the conviction of a physician who may have been acting in good faith in prescribing the drugs.

204 Packer, supra note 6, at 109.

205 See Note, supra note 2, at 1231.

206 See, e.g., Sethi \& Katz, The Expanding Scope of Personal Criminal Liability of Corporate Executives-Some Implications of United States v. Park, 32 Food Drug Cosm. L.J. 544, 546-47 (1977) (arguing that the scope of liability created by Park has introduced "a new element of uncertainty" into corporate decision making).

207 See supra note 206 and accompanying text. 
proof to allow for efficient prosecution when "culpability is likely to be present and yet may be difficult to prove."208 Severe due process problems are inherent in such a tradition, however, because the government cannot rationally define the very standard through which the existence of guilt is determined (strict liability) by reference to a priori assumptions regarding the likelihood of that guilt (that is, that the defendant probably is culpable, but this culpability is shielded from proof).

The federal courts should heed the thrust of Packer's argument that, if a criminal sanction is to result in effective general deterrence, it must be predicated on a carefully articulated objective standard of culpability specifically addressing the individual situation of the actor. ${ }^{209}$ The borrowing of tort law's ordinary negligence standard does not squarely address the issue of criminal culpability since the tort standard evolved primarily to serve the interests of restitution and general deterrence. ${ }^{210}$.In contrast, utilization of the Code's negligence standard, ${ }^{211}$ with or without its requirement of a gross deviation from a standard of care, would assist the trier of fact in a careful and deliberate assessment of each of the elements of a negligence charge. ${ }^{212}$ While the language of the Code establishes culpability through an objective standard, it is attentive to the issue of the justifiability of the risk taken. ${ }^{213}$ Most importantly, it asks the trier of fact to weigh the actor's failure to perceive a given risk in light of the purpose for which the risk was taken and the circumstances actually known to the actor. Such criteria invite a marriage of the objective standard to the subjective context of the actor. They squarely address the issue of individual culpability in failing to meet a normative standard (the culpable "absence of a state of mind") ${ }^{214}$ In terms of the negligence standard of the Clean Water Act, the use of the Code's paradigm can assist the jury's analysis by replacing the intuitive standard of ordinary tort negligence with the analytic rationality of the Code, thus requiring a more deliberate, systematic analysis of

208 Abrams, supra note 4 , at 473 .

209 See Packer, supra note 6, at 109. Packer asserted that "[no] one should be sentenced to imprisonment ... without being afforded the opportunity to litigate the issue of mens rea or, to use the term adopted by the framers of the Model Penal Code, culpability." Id. at 150-51.

210 See Fletcher, supra note 172 , at 243-45.

211 See supra notes 182-89 and accompanying text.

212 See supra notes $182-99$ and accompanying text.

213 See supra notes 185-94 and accompanying text.

214 See supra note 195 and accompanying text. 
both conduct and attribution. ${ }^{215}$ This analysis cannot occur, however, without an equally logical analysis of what constitutes "responsibility" under the responsible corporate officer doctrine.

\section{The "Responsible” Officer and the Negligence Standard}

The "responsible corporate officer doctrine" evolved in a series of cases involving violations of strict liability statutes. This section seeks to show that the Supreme Court has avoided developing any careful definition of the "responsibility" concept. Therefore, the term is surprisingly free to be utilized in a number of situations. Furthermore, the borrowing and insertion of the term "responsible" as the modifier for corporate officers in $\S 1319(c)(6)^{216}$ of the Clean Water Act tends only to compound and exaggerate the uncertainties of the corporate officer responsibility concept in relation to the Act's negligence standard.

\section{A. Background: Sanctioning the Corporation or the Individual?}

The imposition of criminal sanctions on corporate officers without reference to mens rea arose in significant part because of the need to find an effective way to deter corporate conduct deemed harmful to public safety, health and welfare. Since the corporation cannot be incarcerated and its only identity as a "person" is as an economic entity, it is immune from the full weight of criminal sanctions. ${ }^{217}$ Accordingly, there is some reason to believe that the corporation's managers will be more responsive to the threat of sanctions that involve the possibility of personal incarceration.

The "Chicago School" of thought favors focusing criminal sanctions on the corporate entity itself. If the fines are sufficiently substantial, the theory holds, the corporation will take whatever corrective action is necessary to monitor personnel behavior, since its only motive for existence is one of monetary maximization. ${ }^{218}$ This theory asserts that the firm is in a far better position to detect the misconduct of its employees than are governmental enforcement agencies. $^{219}$

This theory is limited, however, by the fact that if the fine is set high enough to be a substantial deterrent, it can damage the financial

215 See G. FLETCHER, supra note 46, at 511-12.

21633 U.S.C. $\S 1319$ (c)(6) (1982 \& Supp. V 1987).

217 See Coffee, supra note 154 , at 390.

218 See R. Posner, Economic Analysis of Law 234-36 (2d ed. 1977).

219 See Coffee, supra note 154 , at 408. 
well-being of those who have no say in the policy-making of the corporation: shareholders, blue collar employees and, often, the dependent surrounding community. ${ }^{220}$ Consequently, there is almost universal agreement that the level of criminal fines currently imposed upon corporations (limited, as they are, by the above concerns) tends to have minimal impact. ${ }^{221}$ As one commentator states, the imposition of fines results in nothing more than "a reasonable license fee" to pollute. ${ }^{222}$

Perhaps in response to the apparent impotence of criminal sanctions as a deterrent force against corporate conduct, Congress has increased the use of federal statutes ${ }^{223}$ that impose direct criminal liability on corporate officers in order to regulate corporate conduct that may result in harm to the public welfare. Some of these statutes stipulate no scienter or meris rea element, subjecting corporate officials to strict liability ${ }^{224}$ for acts or omissions in which they had a "responsible share,"225 but no direct participation or knowledge. ${ }^{226}$ In contrast, other statutes provide for criminal sanctions only when there has been a "knowing violation," thereby substantially increasing the arduousness of the prosecution's burden of proof. ${ }^{227}$ The Clean Water Act, of course, offers yet a third alternative, defining a

220 See id.

221 See, e.g., Reynolds Metals Co. v. Lampert, 324 F.2d 465, 466 (9th Cir. 1963) (noting that an executive in a pollution case testified: "It is cheaper to pay claims than it is to control fluorides."), cert. denied, 376 U.S. 910 (1964); Comment, supra note 100 , at $62.63 \mathrm{n} .9$ ("[C]riminal finess are frequently an impotent and unjust method of dealing with corporate polluters."); Comment, Increasing Community Control over that Corporate Crime-A Problem in the Lazv of Sanctions, 7I YALE L.J. 280, 293 (1961) (stating the real formulators of corporate policy have little to fear from criminal corporate fines because the fines are insubstantial).

222 Comment, supra note 221 , at 287.

223 For a discussion of the increasing reliance on the "deterrent effect of criminal punishment to shape corporate action," see Note, supra note 2, at 1229.

224 While there is some dispute as what the term "strict liability" means, see Abrams, supra note 4 , at $463 \mathrm{n} .3$, this Comment equates the term with those statutes that criminally proscribe conduct without reference to the element of scienter. See, e.g., Wholesome Meat Inspection Act $\$ 406,21$ U.S.C. $\$ 676$ (1982) (criminalizing distribution of adulterated meats without a knowledge requirement); Food, Drug, and Cosmetic Act $\$ \S 31-33,21$ U.S.C. $\$ \S 331-33$ (1982) (criminalizing a variety of acts involving adulterated food, drugs, or cosmetics, such as delivery or misbranding, without requiring knowledge).

225 See infra notes 245-56 for an analysis of the Supreme Court's "responsible share" doctrine.

226 See Brickey, supra note 4, at 1343.

227 See, e.g., Resource Conservation and Recovery Act of 1976, Pub. L. No. 94580,90 Stat. 2811 (1976) (making it a crime for any person knowingly to transport hazardous waste to a facility without a permit) (codified as amended at 42 U.S.C. $\S 6928$ (1982 \& Supp. V 1987)). 
negligence standard of culpability that lies somewhere along the continuum between strictly liable and knowing violations. ${ }^{228}$

\section{B. The Evolution of Strict Liability in the Corporate Context}

Conventional mens rea, which requires that the actor must be aware of the factors making his conduct criminal, places an exceptionally heavy burden on the judicial system. ${ }^{229}$ Thus, the higher the general societal need for deterrence of a specific harm, the greater the reluctance of the legislature may be to impose this burden. This reluctance was first formally addressed by the Supreme Court in Shevlin-Carpenter Co. $v$ Minnesota. ${ }^{230}$ In this early twentieth century case, a company was convicted for cutting timber in violation of a statute that included incarceration as a sanction. ${ }^{231}$ The defendant corporation pleaded that conviction under this statute, which eliminated intent as an element of the offense, violated the fourteenth amendment. $^{232}$ The Court, without explanation or reliance on prior law, rejected the contention that a constitutional protection exists against the imposition of criminal sanctions without proof of mens rea. It asserted quite vaguely that " $[t]$ he Constitution declares the principle upon which the public welfare is to be promoted, and opposing ones cannot be substituted."233 The Court seemed to fear that a constitutional due process review of state legislation would detract from the states' capacity to define and establish remedies for the "public welfare." 234

The next step in the Court's embrace of strict liability came in United States $v$. Balint, ${ }^{235}$ which sustained an indictment for violation of a statute prohibiting the sale of drugs. The Court sustained the indictment despite the defendants' claim that the absence of the element of scienter from the statute violated their due process rights. ${ }^{236}$

228 See 33 U.S.C $\S 1319(c)(1)(1982$ \& Supp. 1987).

229 See Packer, supra note 6, at 109.

230218 U.S. 57 (1910).

231 See id. at 62 \& n.l.

232 See id. at 67.

233 Id. at 68 (citing Connolly v. Union Sewer Pipe Co., 184 U.S. 540,558 (1902), overruled, Tigner v. Texas, 310 U.S. 141 (1940)).

234 "If the principle gets its life or its protection from the Fourteenth Amendment it cannot be destroyed by the legislature upon any conception of the public welfare." Id. Interestingly, the Court was addressing the issue in the same era in which Holmes was asserting his utilitarian philosophy. See supra note 67 and accompanying text.

235258 U.S. 250 (1922).

236 See id. at 254. 
Perhaps the Court did not have the opportunity to review fully the issues, since it rendered the decision after an ex parte proceeding in which the defense presented no oral argument. ${ }^{237}$ Whatever the reason, the Court peremptorily dismissed the due process argument as being settled by Sheolin-Carbenter:

While the general rule at common law was that the scienter was a necessary element in the indictment and proof of every crime... there has been a modification of this view in respect to prosecutions under statutes the purpose of which would be obstructed by such a requirement. ... Many instances of this are to be found in regulatory measures [for the] achievement of some social betterment rather than the punishment of the crimes as in cases of mala in $s e^{238}$

The Balint Court used Shevlin-Carpenter to avoid any substantive discussion of constitutional issues. It also relied on a clear trend in state law favoring the utilization of strict liability statutes, as if the presence of such a large volume of state court approved statutes demonstrated that no constitutional issue could be at stake. ${ }^{239}$

Implicit in the above quotation from Balint is the concept that the statute's strict liability focus is on "social betterment" rather than on punishment. Indeed, the precise nature of the line of strict liability cases to which the Court granted certiorari assured that the issue of incarceration would not be addressed. ${ }^{240}$ The problem with this approach, however, is that the possibility of incarceration is subsumed in the overall validation of strict liability criminal sanctions.

\section{The "Responsible" Corporate Officer and Strict Liability}

United States v. Dotterweich ${ }^{241}$ finally brought the issue of strict criminal liability to bear upon the role of the corporate officer. Dotterweich was the president and manager of a pharmaceutical company that violated the Federal Food, Drug, and Cosmetic Act by shipping misbranded products, an offense for which scienter was not

237 See Packer, supra note 6, at 113.

238 Balint, 258 U.S. at 251-52.

239 See id. at 252.

240 Shevlin-Carpenter Co. v. Minnesota, 218 U.S. 57, 62 (1910), dealt with the sanctioning of the corporate entity only. Balint, 258 U.S. at 254, dealt solely with the framing of an indictment. United States v. Park, 421 U.S. 658, 666 (1975), involved a defendant who had been sentenced simply to pay a fine of fifty dollars on each count. United States v. Dotterweich, 320 U.S. 277, 278 (1943), dealt with a conviction resulting in a fine and a sentence of probation.

241320 U.S. 277 (1943). 
an element. ${ }^{242}$ Despite the fact that the company was not the products' manufacturer and only repackaged them without knowledge of their alteration, ${ }^{243}$ the Court found the president criminally liable:

Whether an accused shares responsibility in the business process resulting in unlawful distribution depends on the evidence produced at the trial .... The offense is committed ... by all who do have such a responsible share in the furtherance of the transaction which the statute outlaws .... Hardship there doubtless may be under a statute which thus penalizes the transaction though consciousness of wrongdoing be totally wanting. Balancing relative hardships, Congress has preferred to place it upon those who have at least the opportunity of informing themselves of the existence of conditions... ${ }^{244}$

The Dotterweich Court simply melds the two issues of strict liability and vicarious liability into one; ${ }^{245}$ if the trier of fact finds that the actor had a "responsible share" in the transaction, the actor is held strictly liable. Moreover, only the trier of fact can determine what constitutes this criminalizing "responsible share." "In such matters," the Court asserted, "the good sense of prosecutors, the wise guidance of trial judges, and the ultimate judgment of juries must be trusted. Our system of criminal justice necessarily depends on "conscience and circumspection in prosecuting officers ...."246 This analysis, however, disregards the judiciary's role. As the dissenters vehemently noted, the United States' system of law is predicated on legislative or judicial definitions of crimes, not prosecutorial discretion. ${ }^{247}$ Without some clear legislative standard of responsibility and judicial interpretation of that standard, one runs the risk under the

242 See id. at 278-81. For two contrasting analyses of the scope of "strict" liability for "responsible" corporate officials under the Food, Drug and Cosmetic Act, see supra note 4.

243 One of the two counts involved the repackaging of a shipment of digitalis that had been received from a wholesaler. The violation occurred because the drug was not the precise strength for which it was labelled, though admittedly there was no way short of conducting a chemical analysis for the company to verified the strength. See Packer, supra note 6, at 116.

244 Dotterweich, 320 U.S. at 284-85 (emphasis added).

245 See Packer, supra note 6, at 117-18. Packer considered this blurring of the two separate elements to be one of the dilemmas making careful analysis of the "responsible share" concept so difficult today. See id.

246 Dotterweich, 320 U.S. at 285 (quoting Nash v. United States, 229 U.S. 373, 380 (1913)).

247 See id. at 292-93 (Murphy, J., dissenting). The dissent noted that such a situation is "precisely what our constitutional system sought to avoid." Id. at 292 (Murphy, J., dissenting). 
Dotterweich standard that the jury alone may determine not just the facts, but the actual scope of criminal liability.

Implied in the concept of "responsible share" in Dotterweich is an allegation of negligent conduct; that is, the officer was in a position of control and, since a violation occurred, the officer presumably failed in his duty to prevent that violation. ${ }^{248}$ One must wonder whether the introduction of the "responsible share" concept was simply a way of defining the scope of liability or whether, quite unintentionally, it began to define an intuitive standard of culpability itself. $^{249}$

In United States $v$. Park, ${ }^{250}$ the Supreme Court affirmed the conviction of the president of a large food chain as "responsible" for a violation of the Food, Drug and Cosmetic Act. In this case, rodent excreta had contaminated warehouse food supplies. ${ }^{251}$ The Fourth Circuit, in reversing the conviction, held that the government had to prove "wrongful action" by the president in its charge that he had a "responsible share."252 The Supreme Court responded that, while it was true that "responsible share" imported some "measure of blameworthiness," the government only need prove that the defendant had, "by reason of his position in the corporation, responsibility and authority either to prevent in the first instance, or to correct promptly, the violation ... and failed to do so."253 Here, the Court's words reflect precisely the words used to define liability for ordinary negligence: the officer had an affirmative duty of care and failed to fulfill that duty. ${ }^{254}$

In his dissent in Park, Justice Stewart immediately noted that the jury hearing the case was not afforded the benefit of this careful "negligence" analysis that defined the scope of the defendant's

248 See Abrams, supra note 4, at 466. Of course, such an allegation is not articulated by the Court. Nevertheless, the prosecutor, the judge and the jury all may sense that they are dealing with culpability, even though it need not be proved under a strict liability statute.

249 Cf. id. (noting "how short a step it is from the responsible share formula to a culpability standard").

250421 U.S. 658 (1975)

251 See id. at 660.

252 United States v. Park, 499 F.2d 839, $841-42$ (1974), rev'd, 421 U.S. 658 (1975).

253 Park, 421 U.S. at 673-74 (emphasis added).

254 The Park decision did narrow the reach of the "responsible share doctrine" as articulated in Dotterweich. Dotterweich appeared to define the "responsible share" in respect to the titular status of the officer, whereas Park examines the officer's relationship to the violation itself. See Note, Individual Liability of Agents for Corporate Crimes Under the Proposed Federal Criminal Code, 31 Vand. L. Rev. 965, 987 (1978). 
"responsible share" liability. ${ }^{255}$ As a consequence, Justice Stewart feared that a jury could convict the corporate officer purely on the basis of his status, since the trial court had not instructed the jury that there must be a failure of a defined duty of care. ${ }^{256}$

Park articulates the proposition that a corporate officer's responsibility, with the attendant duty of "the highest standard of foresight and vigilance" that it imposes, does not create criminal liability if the defendant can show as a defense either that he was " 'powerless' to prevent or correct the violation," or that it was "objectively impossible" for him to prevent the violation. ${ }^{257}$ The potential effectiveness of this defense is illusory, however, because proof of absolute "impossibility" is, so to speak, impossible. ${ }^{258}$ As a last resort, the government can always assert that the corporation could have shut down and avoided risk altogether. ${ }^{259}$

\section{Due Process Judicial Review}

Despite Holmes' professed willingness to sacrifice the individual to achieve effective general deterrence, ${ }^{260}$ the fifth amendment mandates that no one shall be "deprived of life, liberty or property without due process of law."261 The Court during most of this century, however, has ignored the strength of this phrasing, developing an unusual "allergy" when confronted by substantive due process

255 See Park, 421 U.S. at 678-79 (Stewart, J., dissenting).

256 See id. at 679 (Stewart, J., dissenting). The trial judge concluded that, under Dotterweich, the definition of "responsible relationship" was a question for the jury, not the court. The trial judge disagreed with such lack of definition of an element of the offense, but he adhered to it anyway. See id. at $680 \mathrm{n} .1$ (Stewart, J., dissenting).

257 Id. at 673.

258 At least, cases following Park that have raised this defense have met with no success. See, e.g., United States v. Y. Hata \& Co., 535 F.2d 508, 511-12 (9th Cir. 1976) (conviction of corporation and its president affirmed despite defense of "objective impossibility" that installation of preventive device was barred by inability to obtain construction materials), cert. denied, 429 U.S. 828 (1976); United States v. Starr, 535 F.2d 512, 515 (9th Cir. 1976) (conviction of corporation and its secretary treasurer affirmed in that it was not objectively impossible using the "highest standard of foresight" to have foreseen that the plowing of a nearby field would result in a "natural phenomenon" of rodents fleeing for shelter from the field to the warehouse).

259 See, e.g., Y. Hata, 535 F.2d at 511 (noting the prosecution's argument that the "objective impossibility" defense "applies only when the officer was in fact powerless to prevent or correct the violation, even by suspending the corporation's food warehousing activity if necessary").

260 See supra note 1 and accompanying text.

261 U.S. CoNST. amend. V. 
issues. ${ }^{262}$ In the origins of its strict liability interpretation, the Court expressed its reluctance to interfere with legislatures' design of criminal sanctions. ${ }^{263}$ In response, one commentator has termed this action "a blind attempt to tow the substantive-procedural line [in which] the judiciary frequently has unduly compromised its own sense of justice while, ironically, trying to preserve what amounts to nothing more than a conceptually indefensible theory of judicial review." 264

The problem with utilizing the fifth and fourteenth amendments to establish judicial review of legislatively-designed criminal sanctions is the extraordinarily amorphous nature of the term "due process." While appearing to embody a number of protected legal rights, "due process" has no definitive meaning. Indeed, Justice Black expressed the fear that the term could be used to justify judicial fishing expeditions into the legislative domain based on nothing more than vague notions of "natural justice": "[I] do not believe that we are granted power by the Due Process Clause ... to measure constitutionality by our belief that legislation is arbitrary, capricious or unreasonable ... or is offensive to our notions of "civilized standards of conduct." "265

Consistent with such substantive due process fears, the Supreme Court's review of legislatively-enacted criminal sanctions has been limited to the lenient "rational basis" standard. Herbert Packer notes that if this is the limit of the Court's inquiry, then nothing has been asked, since even a statute requiring the boiling in oil of an offender could be considered a "rational" means to achieve the end of effective deterrence. ${ }^{266}$

262 See Robinson v. California, 370 U.S. 660, 689 (White, J., dissenting), reh'g denied, 371 U.S. 905 (1962). Justice White noted that "[i]f this case involved economic regulation, the present Court's allergy to substantive due process would surely save the statute and prevent the Court from imposing its own philosophical predilections upon state legislatures or Congress." Id. (White, J., dissenting).

263 See supra note 232 and accompanying text.

264 Dubin, supra note 201 , at 371 .

265 Griswold v. Connecticut, 381 U.S. 479, 513 (1965) (Black, J., dissenting).

266 Packer comments:

[T] he traditional inquiry of substantive due process is: is there any rational basis (however wrong-headed we may think it) for what the legislature has done? [The inquiry does] not ask the question inherent in the eighth amendment: is what the legislature has done, however rationally supportable it may be, too offensive to stomach? There is nothing irrational about boiling people in oil; a slow and painful death may be thought more of a cleterrent to crime than a quick and painless one. The constitutional objection that would surely prevail is based on decency. 
Given the limited scope accorded substantive due process, the Court intentionally deprives itself of the tools necessary to determine the minimal due process requirements for liberty deprivations under criminal statutes. It is one of the continuing misfortunes in the evolution of strict liability cases through Dotterweich and Park that the absence of the incarceration issue has allowed the Court to finesse due process concerns. ${ }^{267}$ The Clean Water Act itself may provide an opportunity for the Court to address this issue, if it so chooses. The intensity of public concern over environmental pollution well may result in a trial court sentencing a corporate officer in the near future to a substantial jail term for negligent violation of the Act.

\section{CoNCLUSION}

The importance of the "public welfare" issue of environmental pollution is unquestioned; there is an urgent need to vehemently confront the situation without equivocation. ${ }^{268}$ This Comment addresses the issue of achieving maximum deterrence on industries' managers without compromising the due process principles of the Constitution. The Supreme Court has consistently refused to balance perceived individual liberty interests against legislatively defined public welfare needs as the scope of public welfare offenses

Packer, supra note 95, at 1076.

267 See supra notes 54-67 and accompanying text. Morissette v. United States, 342 U.S. 246 (1952), is perhaps the most quoted of all the public welfare cases, but the rigor of its analysis lacks as much as its predecessors. Justice Jackson, writing for the Court, articulates a relatively safe judicial realm for the public welfare offense:

The accused, if he does not will the violation, usually is in a position to prevent it with no more care than society might reasonably expect and no more exertion than it might reasonably exact from one who assumed his responsibilities. Also, penalties commonly are relatively small, and conviction does no grave damage to an offender's reputation.

Id. at 256 (emphasis added).

Justice Jackson's analysis implies that one's sense of justice is not offended when the sanctions imposed are minimal. His analysis leaves unanswered the question of whether the term "relatively small" includes the use of some finite amount of incarceration for strict liability offenses. Obviously, the term "relatively small" inures to the eye of the beholder. For corporate officers, thirty days in jail is likely to be a very long time.

268 See, e.g., High Cost of Deteriorating Environment Is Charted, N.Y. Times, Feb. 12, 1989 , at A4, col. 1 (citing a Worldwatch Institute report asserting that "[ $\mathrm{t}] \mathrm{h}$ ho world can expect widespread economic decline and social disruption in the 1990's unless national leaders make a serious commitment to reverse the deterioration of the earth's environmental systems"). 
gradually evolved. ${ }^{269}$ The development of strict liability case law is thus a "house built on sand," since the Supreme Court cases that laid the foundations for strict criminal liability refrained from analyzing the mens rea element in relationship to the fifth amendment safeguards for deprivation-of-liberty. ${ }^{270}$

The extended reach given strict liability by Dotterweich and Park" 271 to include all those with a "responsible share" in the occurrence compounds this problem. This attenuated interpretation of criminal liability weakens an already careless and "intellectually unsatisfying" Court analysis. ${ }^{272}$ The decision to allow a jury to determine responsibility as an issue of fact without clearly defined guidance from the trial court serves only to undermine further the already weak judicial foundations for liability.

Congress' introduction, however, of at least a nominal mens rea element into the Clean Water Act's criminal sanctions ${ }^{273}$ (as opposed to the Refuse Acr's strict liability provisions ${ }^{274}$ ) initially seemed a positive step towards addressing the due process issue of liberty deprivation. Its negligence standard required at least a minimal assessment of a defendant's "absence of a reasonable state of mind," in that the individual must culpably fail to perceive what a reasonable person would have perceived. ${ }^{275}$ The use of jury instructions in the language of ordinary tort negligence, however, undermines this objective standard. This ordinary negligence approach fails to provide the jury with the analytic tools needed to properly assess the culpable scope of the defendant's alleged deviation from a reasonable standard of care. ${ }^{276}$

Furthermore, the introduction of the words "responsible corporate officer," 277 as borrowed from the strict liability conceptualizations of Dotterweich and Park, circularly allows the assessment of negligence in strict liability terms. As the Park Court defines the term, if the officer is found to be "responsible" in the context of a

269 See supra notes 36-69 and accompanying text for an outline of the broadened scope of public welfare offenses in this century.

270 See supra notes 55-69 \& 269 and accompanying text for a discussion of the absence of the issue of incarceration.

27 I See supra notes 242-60 and accompanying text.

272 Packer, supra note 6, at 152.

273 See supra notes 163-66 and accompanying text.

274 See supra notes $34-48$ and accompanying text.

275 See supra notes 184-97 and accompanying text for a review of the Model Penal Code's criminal negligence standard.

276 See supra notes 211-13 and accompanying text.

277 See supra notes $243-261$ and accompanying text. 
violation, in a sense he is per se negligent. The assessment of role or status readily becomes confused with the assessment of the criminal culpability of negligence. ${ }^{278}$

Given these considerations, the introduction of a negligence standard into the Clean Water Act has not cured the strict liability ills of the Refuse Act. Rather, the ills have spread through the conduit of the "responsible share" doctrine into the judicial interpretations of the Clean Water Act. Both Congress and the Court need to reconceptualize the definition of "responsible share" to remedy this problem. They must establish standards for the determination of any fact concerning "responsible share." Without such a standard, the implementation of the Act's criminal sanctions requires the jury, in determining the scope of the officer's "responsibility," to determine issues that are substantially matters of law. ${ }^{279}$

Finally, trial courts must discontinue the use of a tort ordinary negligence jury instruction for the assessment of criminal culpability under the Clean Water Act. The tort standard was not designed to assess criminal culpability, and is thus an extremely crude analytical tool when used to that end. ${ }^{280}$

In contrast, the Model Penal Code's negligence standard, ${ }^{281}$ even omitting its "grośs deviation" requirement, provides for a precise analysis of an individual's culpable failure to perceive a given risk, as measured against a carefully-articulated, normative standard. ${ }^{282}$ As the Supreme Court recently repeated in Liparota $v$. United States:

"The contention that an injury can amount to a crime only when inflicted by intention is no provincial or transient notion. It is as universal and persistent in mature systems of law as belief in freedom of the human will and a consequent ability and duty of the normal individual to choose between good and evil." 283

In Liparota, the Court, in an opinion delivered by Justice Brennan, reversed the conviction of a store owner for statutory violations in acquiring food stamps. ${ }^{284}$ These violations raised the mens rea issue outside the domain of ninety years of the Court's muddied

278 See supra notes 250-61 and accompanying téxt.

279 See supra notes $247-49$ and accompanying text.

280 See supra note 212 and accompanying text.

281 See supra notes 184-96 and accompanying text.

282 See supra notes $213-17$ and accompanying text.

283471 U.S. 419, 425 (1985) (emphasis added) (quoting Morissette v. United States, 342 U.S. 246, 250 (1952)).

284 See id. at 423. 
interpretation of public welfare law. Considering the Court's capacity to become mute on the issue in the public welfare context, this may have been a fortuitous result. The unequivocal strength of the Court's words, however, offers no restrictions or exceptions: A "mature system of law" will assess the individual's capacity "to choose between good and evil." This Comment urges that the Clean Water Act's usage of a tort ordinary negligence jury instruction, coupled with the "responsible share" doctrine, does not allow, as presently implemented, for a precise assessment regarding that "choice."

Regardless of the extent of public need for protection from environmental harms, the judicial criminal process is not excused from an accurate assessment of culpability for convictions that may result in the loss of a defendant's liberty. The due process mandate of the fifth amendment exist for all; they are not waived simply because of public welfare needs. Justice Rutledge accentuated this point in his dissent in In re Yamashita. ${ }^{285}$ In this case, the Supreme Court affirmed the death sentence of a Japanese general for the atrocities of his troops without proof that the general had knowledge of these acts. Justice Rutledge warned:

Nor has any human being heretofore been held to be wholly beyond elementary procedural protection by the Fifth Amendment. I cannot consent to even implied departure from that great absolute.

It was a great patriot who said: "He that would make his own liberty secure must guard even his enemy from oppression; for if he violates this duty he establishes a precedent that will reach to himself."286

285327 U.S. 1, 41 (1946) (Rutledge, J., dissenting).

$286 \mathrm{Id}$. at 81 (Rutledge, J., dissenting) (quoting 2 The Complete Writings of Thomas Paine 588 (P. Foner ed. 1945)). 